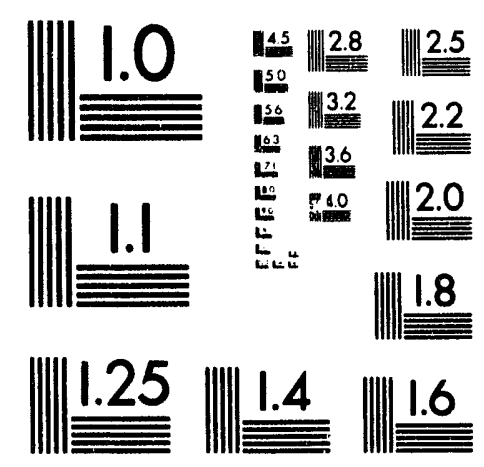



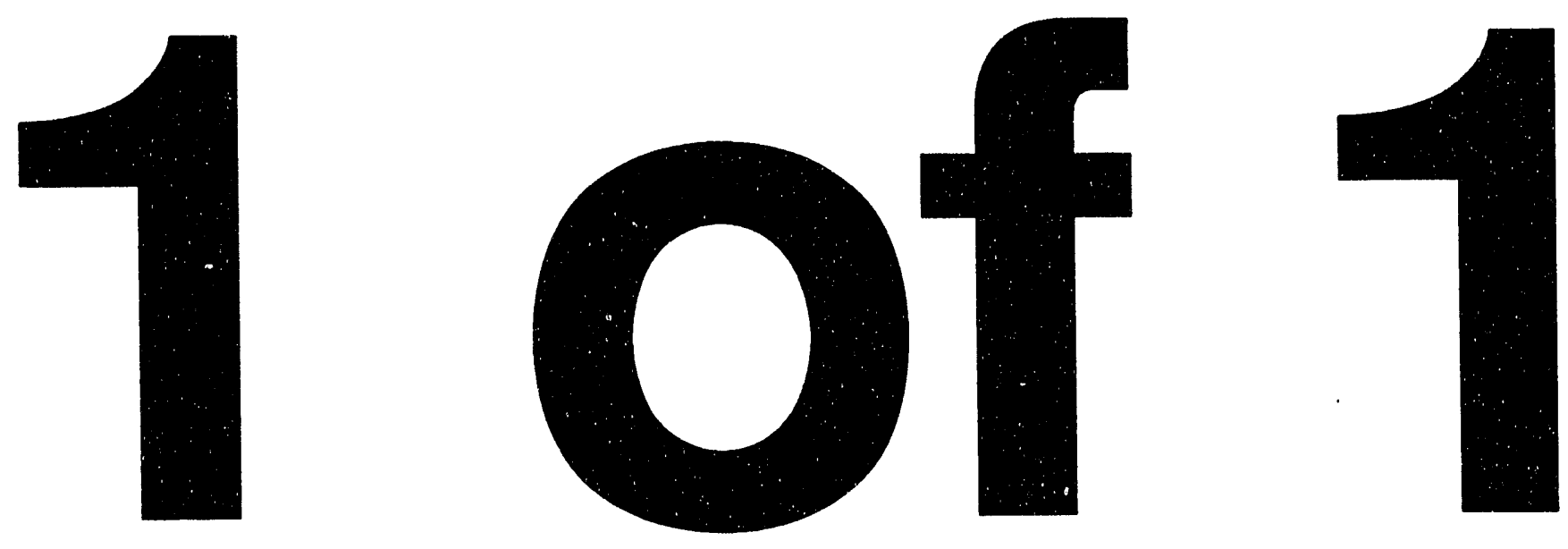


\section{Long-Term Climate Change Assessment Task for the Hanford Site Permanent Isolation Barrier Development Program: Status through FY 1992}

\section{K. L. Petersen}

Westinghouse Hanford Company

J. C. Chatters

Pacific Northwest Laboratory

Date Published

July 1993

Prepared for the U.S. Department of Energy Office of Environmental Restoration and Waste Management

\footnotetext{
(29) Westinghouse P.O. Box 1970

(W) Hanford Compamy Richland, Washington 99352

Hanford Operations and Engineering Contractor for the

U.S. Department of Energy under Contract DE-AC06-87RL10930
} 


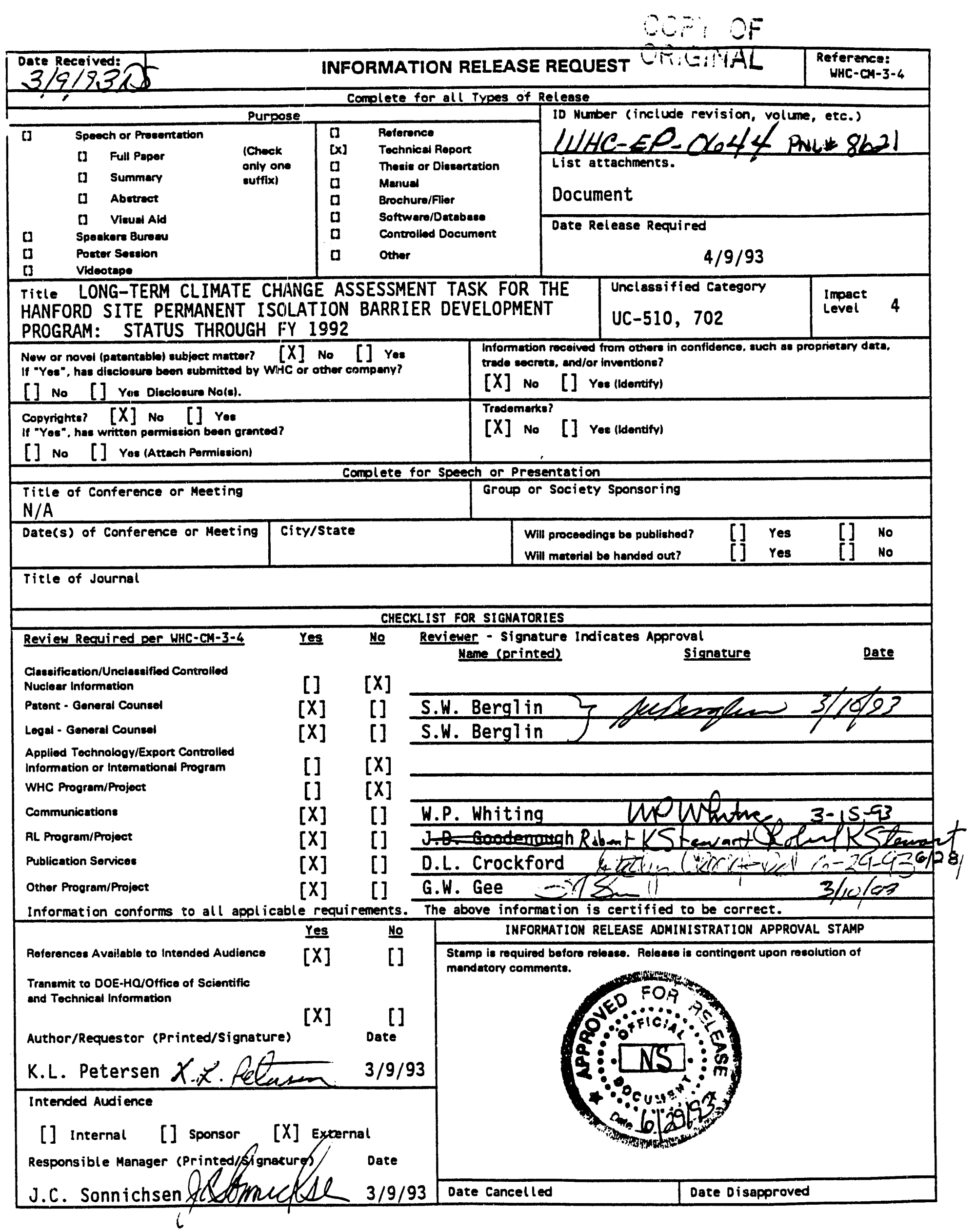




\section{LONG-TERM CLIMATE CHANGE ASSESSMENT TASK FOR THE HANFORD SITE PERMANENT ISOLATION BARRIER DEVELOPMENT PROGRAM:

\section{EXECUTIVE SUMMARY}

The Hanford Site Permanent Isolation Barrier Development Program (Barrier Development Program) was organized to develop the technology needed to provide an in-place disposal capability for the U.S. Department of Energy at the Hanford Site in southeastern Washington. The goal of the Barrier Development Program is to provide defensible evidence that final barrier design(s) will adequately control water infiltration, plant and animal intrusion, and wind and water erosion for a minimum of 1,000 years; to isolate wastes from the accessible environment; and to use markers to warn inadvertent human intruders. Evidence for barrier performance will be obtained by conducting laboratory experiments, field tests, computer modeling, and other studies that establish confidence in the barrier's ability to meet its 1,000-year design life. The performance and stability of natural barrier analogs that have existed for several millennia and the reconstruction of climate changes during the past 10,000 years and beyond also will provide insight into bounding conditions of possible future changes and increase confidence in the barriers design.

Climate will have pervasive influence on barrier performance. Soil water movement will be affected by changes in precipitation, temperature, and vegetation. Climatically induced changes in plant and animal communities will affect the potential for biointrusion. Surface stability may be impacted by changes in wind patterns, but also by changes in vegetation cover that may result from climatic change. 
Currently, the potential future climate variation and vegetation change in the Pasco Basin for the next millennium is largely unknown. Consequently, the effects of climatic variability on barrier performance have not been evaluated adequately. The Basalt Waste Isolation Project (BWIP) had developed plans for characterizing long-term changes in Pasco Basin climate, some of which the Barrier Development Program proposed to use; however, with the closing of BWIP, the Barrier Development Program's plans for obtaining much of its climatic information from BWIP changed and a new research strategy was developed in the Long-Term Climate Change Assessment Study Plan for the Hanford Site Permanent Isolation Barrier Development Program." This study plan details the research approach to be taken to obtain defensible projections of climate parameters based on studies of current climate, past climate, and projected future climate. The overall objective of the Long-Term Climate Change Task is to accomplish the following:

- Obtain defensible probabilistic projections of the long-term climate variability in the Hanford Site and Pasco Basin region

- Develop several test-case climate scenarios that bracket the range of potential future climate

- Use the climate scenarios to both test and model barrier performance.

\footnotetext{
"Petersen, K. L., J. C. Chatters, and W. J. Waugh, 1992, Long-Term Climate Change Assessment Study Plan for the Hanford Site Permanent Isolation Barrier Development Program, WHC-EP-0569, Westinghouse Hanford Company, Richland, Washington.
} 
WHC-EP-0644

This document describes the accomplishments for fiscal year 1990, fiscal year 1991, and fiscal year 1992 based on those approaches. Specific progress is reported for Task Administration (Task 0 ), Identification of Climatic Data Needs (Task 1), Synthesis of Existing Information (Task 2), Pollen and Lake Sediment Studies (Task 3), and Terrestrial Sediment Studies (Task 5). 
WHC-EP-0644

This page intentionally left blank. 


\section{CONTENTS}

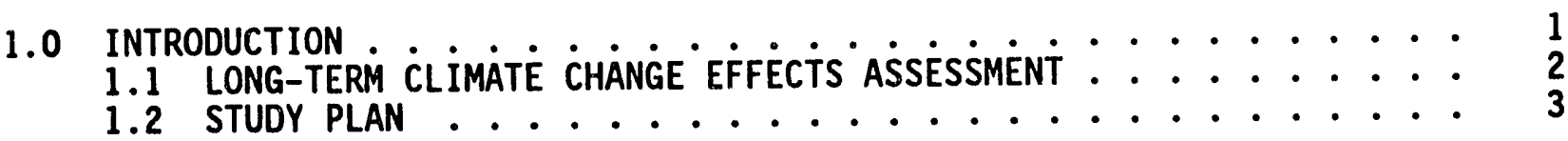

2.0 TASKS jisK $\dot{0}^{\circ}$ TASK ADMINISTRATION . . . . . . . . . . . 4

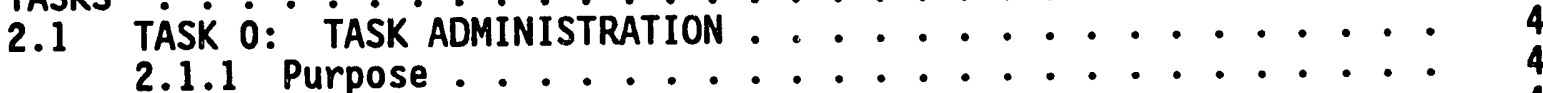

2.1.2 Accomplishments . . . . . . . . . . . . . . 4

2.2 TASK 1 : IDENTIFICATION OF CLIMATIC DATA AND SENSITIVITY . . 5

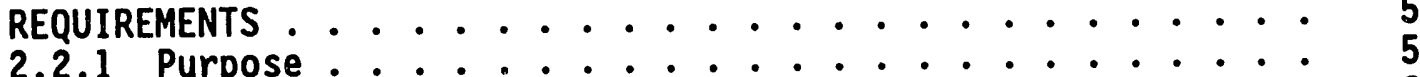

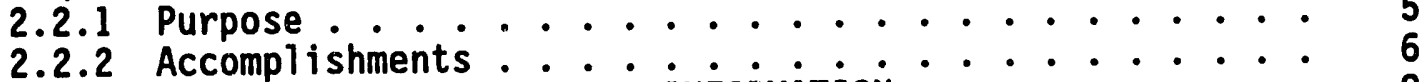

2.3 TASK 2: SYNTHESIS OF EXISTTING INFORMATION . . . . . . . . 9

2.3.1 Purpose ..................... 9

2.3.2 Accomplishments ................. . 9

2.4 TASK 3: POLLEN AND LAKE SEDIMENT STUDIES . . . . . . . . . . 17

2.4.1 Purpose ..................... 17

2.4.2 Accomplishments . . . . . . . . . . . . . 17

2.5 TASK 4: FLUVIAL SEDIMENT AND GROUNDWATER STUDIES . . . . . . 20

2.5.1 Fluvial Indicators . . . . . . . . . . . . . 20

2.5.2 Feasibility Study for Episodic Groundwater Recharge . . 21

2.6 TASK 5: TERRESTRIAL SEDIMENT STUDIES . . . . . . . . . . . 21

2.6.1 Studies of Eolian Processes . . . . . . . . . . . 22

2.6.2 Faunal Indicators . . . . . . . . . . . . . 24

2.7 TASK 6: PAST CLIMATE/VEGETATION VARIATIONS $\cdot \cdot \cdot \cdot \cdot \cdot \cdot \cdot \cdot 25$

2.8 TASK 7: FUTURE CLIMATE/VEGETATION PROJECTIONS . • . • . . . . 25

2.9 TASK 8: LOCAL CLIMATE FORECAST MODEL AND TASK 9: MODEL. .25

2.10 TASK 10: PROJECTION OF FUTURE CLIMATES . . . . . . . . . . 26

2.11 TASK 11: GENERATION OF WEATHER STATISTICS . . . . . . . . . . 26

2.12 TASK 12: IDENTIFICATION OF SPACIAL ANALOGS OF

VEGETATION RESPONSE TO PROJECTED CLIMATES

2.13 TASK 13: INPUT CLIMATIC DATA TO BARRIFR PERFORMANCE
ASSESSMENT . . . . . . . . . . . . . . . . . 26

3.0 REFERENCES . . . . . . . . . . . . . . . . . . . 27 
WHC-EP-0644

\section{TABLE}

1 Summary of Environmental Parameters Needed by Barrier Development Studies To Assess Long-Term Performance 


\subsection{INTRODUCTION}

The Hanford Site Permanent Isolation Barrier Development Program (Barrier Development Program) was organized (Adams and Wing 1986) to develop the technology needed to provide an in-place disposal capability for the U.S. Department of Energy at the Hanford Site in southeastern Washington. The goals of the Barrier Development Program are to provide defensible evidence that final barrier design(s) will adequately control water infiltration, plant and animal intrusion, and wind and water erosion for a minimum of 1,000 years; to isolate wastes from the accessible environment; and to use markers to warn inadvertent human intruders. Evidence for barrier performance will be obtained by conducting laboratory experiments, field tests, computer modeling, and other studies that establish confidence in the barriers ability to meet its 1,000-year design 1 ife. The performance and stability of natural barrier analogs that have existed for several millennia and the reconstruction of climate changes during the past 10,000 to 125,000 years al so will provide insight into bounding conditions of possible future changes and increase confidence in the barriers design. In the following discussion the term "long-term" references periods of time up to 1000's of years, distinguishing it from "short-term" weather patterns covering a decade or less.

Specific activities focus on planning and conducting a series of studies and tests required to confirm key aspects of the barrier design. The effort is a collaborative one between scientists and engineers from Westinghouse Hanford Company (Westinghouse Hanford) and Pacific Northwest Laboratory (PNL) to design barriers to 1 imit movement of radionuclides and other contaminants to the accessible environment for at least 1,000 years. These activities have been divided into the following 14 groups of tasks that aid in the complete development of protective barrier and warning marker system:

- Project management

- Biointrusion control

- Water infiltration control

- Erosion/deposition control

- Physical stability testing

- Human interference control

- Barrier construction materials procurement

- Prototype barrier designs and testing

- Model applications and validations

- Naturar analog studies

- Long-term climate change effects

- Interface with regulatory agencies

- Technology integration and transfer

- Final design.

The purpose of this document is to describe the activities and some of the results obtained during fiscal year (FY) 1990, FY 1991, and FY 1992 by Westinghouse Hanford and PNL through the execution of portions of the LongTerm Climate Change Assessment Study Plan for the Hanford Site Permanent Isolation Barrier Development Program (Petersen et al. 1992), which addresses the objectives outlined in the Long-Term Climate Change Effects Task of the Protective Barrier and Warning Marker System Development Plan (Adams and Wing 1986) and provides input for the update of that document. 
WHC-EP-0644

\subsection{LONG-TERM CLIMATE CHANGE EFFECTS ASSESSMENT}

The specific purpose of the Long-Term Climate Change Effects Assessment as outlined in Protective Barrier and Warning Marker System Development Plan (Adams and Wing 1986) is to address issues concerning future climate change and the possible effects that it might have on barrier performance. Such changes in climate are likely to have pervasive influence. Soil water movement will be sensitive to changes in precipitation, temperature, and the water extraction characteristics of plants growing on the barrier.

Biointrusion analyses must account for climate-induced changes in plant root distribution and animal burrowing. These factors, plus changes in strength and direction in the wind regime, may impact surface stability. Currentiy, the possible 1,000-year variation in the climate ard ecology of the Pasco Basin are largely unknown.

The overall focus of this assessment is to provide comprehensive, welldocumented characterizations of past and potential climatic and environmental changes that will help satisfy (1) design and regulation requirements, (2) barrier performance assessment requirements, and (3) hydrologic and other barrier task input needs. The objective of the climate change effects tasks is to obtain projections of the potential long-term variability of climate and other environmental factors and their associated probabilities of occurrence in the Pasco Basin that can be combined with analyses of water balance, biointrusion, and erosion of protective barriers. A multi-disciplinary approach to climatic data acquisition is being relied on to obtain the needed information for use by concurrent barrier tasks and to develop a local climate forecast model or models.

The objectives of Task CLIM-1, "Evaluate Climate Informational Needs," include (1) identifying specific parameters of long-term climate that will be required for water infiltration, erosion, and biointrusion analyses, (2) evaluating the adequacy of existing information, and (3) determining the approach for acquiring any needed information. The task comprises the following activities:

- Prepare a long-term climate change assessment study $\mathrm{pl}$ an based on existing, applicable Basalt Waste Isolation Project (BWIP) study plans (complete)

- Have an offsite peer review of the long-term climate change assessment study plan (complete)

- Finalize the climate study plan (complete)

- Identify the key climate parameters for input to barrier performance analys is (complete)

- Evaluate the adequacy of existing data (complete).

The research approach of Task CLIM-2, "Predict Local C1 imate and Vegetation Changes," is to develop a local climate forecast model or models. Conceptually, this model (or models) is envisioned as coupling past climate patterns with models of regional and global climate drivers to provide 
patterns with models of regional and global climate drivers to provide bounding conditions for barrier performance assessment analyses. This task comprises the following activities:

- Execute the climate study plan (in progress)

- Reconstruct the local paleoclimates (in progress)

- Develop and calibrate the local climate forecast models

- Predict probable changes in precipitation and temperature

- Predict probable changes in the wind regime

- Predict probable climate-induced changes in vegetation

- Report the results of this task for use by tasks dependent on the data.

\subsection{STUDY PLAN}

The study plan strategy for obtaining an understanding of the range and probability of recurrence of past climate change and for a projection of potential future climate at the Hanford Site is development and execution of a series of task studies. These task studies provide a methodical approach to developing defensible prediction of potential future climate states. The modular form of the climate study plan has been designed to provide an overall research strategy that can be scaled to accommodate future funding uncertainties or to be used for other applications that might need climate information. These tasks and subtasks have been numbered in the following manner:

- 0 . Task Administration

- 1. Identification of Climatic Data Needs

- 2. Synthesis of Existing Information

- 2.1 Modern Climatic Patterns

- 2.2 Holocene Paleoclimate Literature

- 2.3 Late Quaternary Literature

- 2.4 Flood Records

- 2.5 Global Climate Modeling

- 3. Pollen and Lake Sediment Studies

- 3.1 Scablands Pollen Site Transect

- 3.2 Full Glacial Pollen Study

- 4. Fluvial Sediments and Groundwater Studies

- 4.1 Fluvial Indicators

- 4.2 Episodic Groundwater Recharge

- 5. Terrestrial Sediment Studies

- 5.1 Studies of Eolian Processes

- 5.2 Faunal Indicators

- 6. Past Climate/Vegetation Variations

- 7. Future Climate/Vegetation Projections

- 8. Local Climate Forecast Model

- 9. Model Calibration and Validation 
- 10. Projection of Future Climates

- 11. Generation of Weather Statistics

- 12. Identification of Future Spatial Analogs

- 13. Input to Barrier Performance Assessment.

The remaining portion of this document briefly outlines the purpose of each task and reports the technical progress accomplished as well as describes some of the initial findings.

\subsection{TASKS}

\subsection{TASK 0: TASK ADMINISTRATION}

\subsubsection{Purpose}

The purpose of the task of administration is to coordinate and integrate the effurts being performed by Westinghouse Hanford and PNL in support of the Hanford Protective Barrier Long-Term Climate Change Assessment Task and the Long-Term Climate Change Assessment Study Plan for the Hanford Site Permanent Isolation Barrier Development Program (Petersen et al. 1992). Planning, scheduling, budgeting, contract administrating, performing tasks, and interfacing with other Barrier Development Program tasks are essential activities that must be coordinated. The Long-Term Climate Change Assessment Tasks require that personnel remain cognizant of technical advances in the area of climate assessment by reviewing technical journals and attending seminars and conferences (as funding permits) so that the information gleaned from such efforts can help ensure that complicated issues are resolved in a cost-effective, timely, and technically sound manner.

\subsubsection{Accomplishments}

In late FY 1989 an independent third-party technical peer review of a draft study plan was conducted. That draft study plan reflected an integration of plans first developed for BWIP with the needs of the Barrier Development Program. The third-party review was undertaken to ensure the adeanuacy of the strategy and completeness of the long-range climate change effect; assessment program (for a more detailed discussion see Petersen et al. 1992.).

The FY 1990 preliminary report on the third-party review was received from Golder Associates Incorporated (GAI), Seattle, and was reviewed by Westinghouse Hanford and PNL. Based on the final GAI review report, a revised outline for the study plan was developed to allow implementation of the recommendations of the review panel, and writing assignments were divided between Westinghouse Hanford and PNL personnel. The completed sections-were integrated into a single document. 
Petersen et al. (1992) contains task description, preliminary budget estimates, and schedules. Based largely on the recommendations of the independent third-party review, the program has become more focused and the cost of performing the work has been reduced from an initial estimate based on applicable BWIP cost figures in FY 1988 of $\$ 3.4$ million to a current estimate of about $\$ 1.9$ million contained in the current study plan. This amount could be reduced even more depending on the outcome of critical decision points in the work strategy. A modular form will allow for scaling the program depending on availability of funding and will allow for the adaption of the research strategy to other projects or programs that require climate change data.

Other accomplishments include attendance of Westinghouse Hanford and PNL personnel at a number of meetings and workshops including the Barrier Technical Advisory Board meetings and the Interlab/Interagency Protective Barrier Workshop convened at the Hanford Site (August 9-10, 1990), with representatives from Los Alamos National Laboratory, Idaho National Engineering Laboratory, Idaho State University, Jacobs Engineering, U.S. Environmental Protection Agency, and Washington State Department of Ecology.

\subsection{TASK 1: IDENTIFICATION OF CLIMATIC DATA AND SENSITIVITY REQUIREMENTS}

\subsubsection{Purpose}

An all-encompassing requirement in the process of designing and testing barriers is understanding the interaction among design components and environmental and climatic factors. Water movement within layered soil systems is related to changes in surface soils, precipitation, temperature, and water extraction characteristics of plants. Changes in climate also may alter the structure of plant and animal communities inhabiting the area and, thus, the potential for biointrusion. Biointrusion studies may need to account for the influence of climate on plant-rooting depths and the regional distribution and behavior of burrowing animals. Changes in plant cover, burrowing animal behavior, precipitation and temperature, as well as wind regimes, may influence the stability of the barrier surface. Currently, the possible future 1,000-year variation in the climate and ecology of the Pasco Basin is largely unknown. If such a long time frame is to be considered, more information must be obtained about the past and potential range of key climatic variables.

Task 1 is a first step in assessing the effects of climatic change on the long-term performance of protective barriers. The objectives of this task are the following:

- Identification of specific climatic parameters that will be required by the various studies of long-term barrier performance

- Identification of the temporal resolution and precision required for each climatic parameter 
- Conducting of climatic sensitivity analyses to assess the relative importance of climatic parameters

- Development of a task hierarchy, task priority ranking, and task sequence for the timely acquisition of needed climatic data.

\subsubsection{Accomplishments}

Petersen et al. (1992) provides a preliminary survey of the climatic parameters required by the various barrier development studies. The following table (Table 1) from Petersen et al. (1992) lists a summary of the findings of that survey. The requirements likely will be modified in the future as work on the various studies moves ahead and the results of climatic sensitivity analyses become available. Currently it is not feasible to organize data needs into task sequences, hierarchies, or priority rankings. This will require additional input from Barrier Development Program task project managers.

The U.S. Department of Energy is required to prepare performance assessments for the disposal of all of its radioactive wastes. The objective of current design efforts for the Barrier Development Program is to use natural materials to develop a maintenance-free permanent isolation barrier and warning marker system that isolates wastes for a minimum of 1,000 years by limiting water drainage to near-zero amounts; reducing the likelihood of plant, animal, and human intrusion; controlling the exhalation of noxious gases; and minimizing erosion-related problems. To aid in the development of protective barrier and warning markers systems, the following list of preliminary performance objectives have been defined.

- The systems must be able to function in a semiarid to subhumid climate.

- The design objective selected based on preliminary performance assessments that supported the preparation of the Final

Environmental Impact Statement for the Disposal of Hanford Defense High-Level, Transuranic, and Tank Wastes (DOE-RL 1987) includes limiting the recharge of water through the waste to the water table to near-zero amounts $\left(0.05 \mathrm{~cm}\right.$ of water per year $\left.\left[1.6 \times 10^{-9} \mathrm{~cm} / \mathrm{s}\right]\right)$.

- The systems must be maintenance free.

- The systems must endure for a minimum of 1,000 years.

In demonstrating that these performance objectives can be met, climate concerns must be addressed. Global climates have undergone significant variations in the past, and such variations are expected to continue. This expectation is reflected in a number of the public comments recorded in the Final Environmental Impact Statement for the Disposal of Hanford Defense HighLevel, Transuranic, and Tank Wastes (DOE-RL 1987), which indicate the consideration of future climatic change is cursory and the method of disposal of waste should consider defensible projections of future climatic variability for the Hanford Site region. 
Table 1. Summary of Environmental Parameters Needed by Barrier Development Studies to Assess Long-Term Performance (Petersen et al. 1992). (sheet 1 of 2)

\begin{tabular}{|c|c|}
\hline Issues and Studies & Parameters \\
\hline \multicolumn{2}{|c|}{ Issue: Hydrologic Performance } \\
\hline 1. Field Lysimeter Test Facility & $\begin{array}{l}\text { Precipitation: Annual mean, monthly } \\
\text { means, storm frequency, storm } \\
\text { intensity. } \\
\text { Vegetation: species composition, } \\
\text { abundance, and phenology. }\end{array}$ \\
\hline 2. Soil Water Balance Modeling & $\begin{array}{l}\text { Input parameters: Hourly, daily, or } \\
\text { monthly precipitation, surface soil } \\
\text { temperature, atmospheric relative } \\
\text { humidity; mean annual solar } \\
\text { radiation. }\end{array}$ \\
\hline 3. Evapotranspiration Modeling & $\begin{array}{l}\text { Parameters controlling stomatal } \\
\text { conductance: light intensity, light } \\
\text { quality, carbon dioxide } \\
\text { concentrations, precipitation, } \\
\text { temperature, atmospheric relative } \\
\text { humidity, wind speed. } \\
\text { Plant communities: species } \\
\text { composition, relative abundance, } \\
\text { m leaf area, biomass. }\end{array}$ \\
\hline 4. Alternative Barrier Tests & $\begin{array}{l}\text { Precipitation: Annual mean, monthly } \\
\text { means, storm frequency, storm } \\
\text { intensity. } \\
\text { Vegetation: Species composition and } \\
\text { abundance. }\end{array}$ \\
\hline \multicolumn{2}{|c|}{ Issue: Erosion, Deposition, and Structural Stability } \\
\hline $\begin{array}{l}\text { 1. Wind Erosion and Deposition } \\
\text { Tests }\end{array}$ & $\begin{array}{l}\text { Wind: Annual or monthly mean } \\
\text { velocity and direction; velocity, } \\
\text { frequency, and duration of peak gust } \\
\text { events. } \\
\text { other: Annual and monthly mean } \\
\text { precipitation; monthly means and } \\
\text { ranges of temperature; plant cover } \\
\text { as a soil stability factor. }\end{array}$ \\
\hline
\end{tabular}


Table 1. Summary of Environmental Parameters Needed by Barrier Development Studies to Assess Long-Term Performance (Petersen et a1. 1992). (sheet 2 of 2)

\begin{tabular}{|c|c|}
\hline Issues and Studies & Parameters \\
\hline $\begin{array}{l}\text { 2. Water Erosion and Sideslope } \\
\text { Stability }\end{array}$ & $\begin{array}{l}\text { Precipitation: Rainfall amount; } \\
\text { duration and return frequency of } \\
\text { high-intensity storms. } \\
\text { Vegetation: Plant cover } \\
\text { characteristics influencing soil } \\
\text { stability }\end{array}$ \\
\hline $\begin{array}{l}\text { 3. Gravel Mulch Effects on } \\
\text { Hydrologic Performance }\end{array}$ & $\begin{array}{l}\text { Precipitation: Annual and monthly } \\
\text { means, storm frequency, storm } \\
\text { intensity. } \\
\text { Vegetation: Species composition and } \\
\text { abundance. }\end{array}$ \\
\hline \multicolumn{2}{|c|}{ Issue: Biological Intrusion } \\
\hline 1. Biointrusion Control Tests & $\begin{array}{l}\text { Vegetation: Species composition, } \\
\text { abundance, spatial distribution. } \\
\text { Precipitation: Annual and monthly } \\
\text { means, snow accumulation, drought } \\
\text { frequency and duration, atmospheric } \\
\text { relative humidity. } \\
\text { Temperature: Seasonality, diurnal } \\
\text { fluctuation, frequency and duration } \\
\text { of extreme warm and cold periods. } \\
\text { other: Wind speed, carbon dioxide } \\
\text { concentrations, atmospheric } \\
\text { pollutants. }\end{array}$ \\
\hline
\end{tabular}


WHC-EP-0644

\subsection{TASK 2: SYNTHESIS OF EXISTING INFORMATION}

\subsubsection{Purpose}

The available published literature will form the basis for developing a systematic understanding of the nature, magnitude, and rate of past and potential climatic change in the Pacific Northwest. The purpose of this task is to review and analyze extant literature and records and integrate the results into climatically or hydrologically meaningful synopses. Based partly on the recommendations of the technical review panel (Petersen et al. 1992), the synthesis of paleoclimatic/paleoenvironmental information will focus on the local and regional paleoclimates for the extreme climatic periods identified 125,000 years, 18,000 years, 9,000 years, 6,000 years, and 3,500 years ago. These reconstructions will be compared and contrasted to present and other available global climate modeling simulations for those time intervals to constrain climatic parameters. These then can be used to ascertain the potential for impacting the protective barriers if such climatic extremes were to occur in the future. The review of literature is divided into five subtasks: (1) Modern Climatic Patterns, (2) Holocene Paleoclimatic Literature, (3) Late Quaternary Paleoclimate Literature, (4) Flood History, and (5) Global Climate Modeling. These subtasks will help to identify areas that are addressed sufficiently by extant literature and areas that need further study.

\subsubsection{Accomplishments}

2.3.2.1 Modern Climatic Patterns. Understanding modern climatic patterns gives a better basis for evaluating past and potential future changes. In addition, historic characteristics of extreme events and changes of seasonality ultimately may give insight to important controlling variables to be considered in assessing climatic impacts to protective barrier performance. Reported here are some of the preliminary findings for this subtask.

Stone et al. (1983) summarizes the present climate for the Hanford Site. The climate for the Hanford Site is influenced greatly by being in the rain shadow of the Cascade Mountains. The Hanford Meteorological Station and the proposed prototype barrier site are situated on a plateau at about $215 \mathrm{~m}$ elevation. The plateau slopes downward toward the Columbia River at roughly $105 \mathrm{~m}$ elevation about $16 \mathrm{~km}$ to the north and slopes upward to the foothitis of the Rattlesnake Mountains about $16 \mathrm{~km}$ south.

Precipitation at the Hanford Meteorological Station averages $15.88 \mathrm{~cm}$ annually. Forty-four percent of this total occurs November through January; only 13 percent occurs July through September. On average, there are only two occurrences per year of 24-hour amounts of precipitation of $1.27 \mathrm{~cm}$ or more, while there were occurrences of 24-hour amounts of $5.08 \mathrm{~cm}$ or more only 2 the entire 35 years recorded (1946-1980). One of these was the record storm of October 1-2, 1957, during which rainfall totalled $2.74 \mathrm{~cm}$ in 3 hours, $4.27 \mathrm{~cm}$ in 6 hours, and $4.78 \mathrm{~cm}$ in 12 hours. Based on extreme value analysis of records for 1947 through 1969, the average return period and existing record for various precipitation amounts and intensity during specified time periods at the Hanford Site suggest that the 60-minute storm recording period 
(expected once during a 100-year period) would result in $2.06 \mathrm{~cm}$ of precipitation. The 60-minute storm recording period (expected once during a 1,000-year period) would result in $2.82 \mathrm{~cm}$. (No records have been kept for time periods less than 60 minutes; however, the rain gauge chart for June 12 , 1969 , shows that $1.40 \mathrm{~cm}$ occurred during a 20-minute period.) A 24-hour maximum accumulation for a 100-year return period is $5.05 \mathrm{~cm}$ and the 1,000 -year return is $6.81 \mathrm{~cm}$.

About 38 percent of all precipitation during December through February is in the form of snow. Accumulation of as much as $15.24 \mathrm{~cm}$ is expected in only one winter out of four. There is an average of 4 seasonal days with $15.24 \mathrm{~cm}$ or more of snow, although the 1964-1965 winter had 35 days, 32 of which were consecutive. That winter also provided one of the greatest depths when $30.7 \mathrm{~cm}$ of snow fell in December 1964. The greatest depth of snow recorded is $62.2 \mathrm{~cm}$, which occurred in February 1916.

The average monthly temperature at the Hanford Meteorological Station is $11.6{ }^{\circ} \mathrm{C}$. However, temperatures at the Hanford Site are colder in the winter (January monthly average is $-1.5^{\circ} \mathrm{C}$ ) and warmer in the summer (July monthly average $24.7^{\circ} \mathrm{C}$ ) than sites west of the Cascades, because the mountains cut it off from the moderating influence of maritime air. However, it is less continental than many other areas of the interior west because other mountain ranges to the north and east shield the area from many of the arctic surges and half of all winters are free of temperatures as low as $-17.8{ }^{\circ} \mathrm{C}$. Although temperatures reach $32{ }^{\circ} \mathrm{C}$ or above an average of 55 days a year, minimum temperatures of $21.1{ }^{\circ} \mathrm{C}$ or above occur only an average of 8 days a year. The unusually cool nights result from cool gravity winds originating from the Cascade Mountains.

To understand how characteristic these climatic conditions are to the Pasco Basin, it is valuable to review regional patterns from a reasonably long period of time. Climatic "variation" refers to systematic changes of temperature, precipitation, and other climatic variables during the past 100 years as revealed in historical series of quantitative meteorological observations (Mitchel1 1987). Climatic variation specifically refers to changes of average climate between periods, each of which was decades or more in duration. The current practice is to calculate the statistical characteristics of 30-year periods (i.e., three adjacent decades) and to define the statistics as describing the "30-year normal" climate for the weather station. A new 30-year normal is calculated with the completion of each new decade by averaging that decade with the previous two decades. The year-to-year (or longer) variation usually is compared to the normal current period. Slower climatic changes with periods of time comparable to or exceeding the length of available observations are known as secular variations.

Recent changes in a number of proxy records have indicated that changes have occurred in the pattern of climate in the Pacific Northwest. Some of these changes will be discussed next. One study option that has been useful in reviewing climate patterns for a time period of decades to centuries is Dendroclimatic reconstructions using tree-ring analysis. Trees in temperate regions produce annual growth layers (or rings) that often display common year-to-year variability in size, structure, and chemical composition. 
Because climate is the principal driver of growth-ring variability common to many trees in an area, it is possible to reconstruct year-to-year climatic records from growth rings.

Cropper and Fritts (1986) and Gramulich (1987) are two studies of particular interest for characterizing recent climatic patterns in the Northwest. Cropper and Fritts (1986) derived a 360-year regional reconstruction of seasonal and annual variations in temperature and precipitation from statistical relationships between meteorological records from Columbia Basin stations and tree-ring data from throughout western North America. Using similar methods, Gramulich (1987) compared 300-year precipitation reconstructions for three regions in the Pacific Northwest. Gramulich used subsets of records from a network of meteorological stations and tree-ring data from each region.

Cropper and Fritts (1986) calibrated the relationship between Columbia Basin weather records and a network of 65 tree-ring chronologies by applying canonical stepwise multiple regression to principal components of tree growth indices and principal components of climate. The best of the network of reconstructions were averaged to produce regional reconstructions. The results suggest that the average temperature of the Columbia Basin for the last three centuries was slightly higher $\left(0.09^{\circ} \mathrm{C}\right)$ and more variable (4 percent higher standard deviation) than the 20 th Century. The increase was primarily attributed to warmer winters. The reconstructions also suggest that the last 3 centuries were wetter on average $(0.81 \mathrm{~cm})$, primarily in the fall. Furthermore, droughts apparently were more frequent in the second half of the 17 th Century and lasted longer than droughts of the 20th Century.

Gramulich (1987) also used multiple regression models to reconstruct precipitation in the Pacific Northwest. Polynomial and exponential curvefitting and autoregressive-integrated-moving-average (ARIMA) models were applied to remove nonclimatic growth trends and autocorrelation from the tree-ring chronologies. Separate reconstructions were derived for three climatic regions: Columbia Basin (eastern Washington and northeastern Oregon), Western Lowlands (western Washington and Oregon), and Southern Valleys (southeastern Oregon and northern Cal ifornia). The results indicate that the average precipitation of the 18th and 19th Centuries did not differ from the average precipitation of the 20th Century. The reconstructions also indicate that extreme drought years, caused by high-pressure ridges shifting storm tracks to the north during normally wet winter months, were common to all regions in the Pacific Northwest.

An early 19th Century wet period in the Columbia Basin was a time of extended drought in southern Oregon and northern California, and while the Columbia Basin was experiencing a late 19th Century drought, southern Oregon and northern California were wetter than normal. Gramulich (1987) attributes these contrasting north-south patterns to latitudinal variation in the position of the polar jet stream in the winter and subtropical high-pressure cells in the summer. The long-term average position of these local climate drivers likely will be impacted by global climatic change in the future. This underscores the need for adequate local paleoclimatic data to better understand the influence of global climatic change in the Pasco Basin. 
In another study, Burbank (1982) correlated climate, glacial mass balances, and glacial fluctuations at Mount Rainier in the Washington Cascade Mountains since 1850 and concluded that, based on the analyses of the reconstructed temperature record and former ice frontal positions, as much as a $1-{ }^{\circ} \mathrm{C}$ temperature rise has occurred since the period of 1770 to 1830 , the bounding dates of the latest Neoglacial or Little Ice Age advance at Mount Rainier. Ebbesmeyer et al. (1989) suggests an interesting causal link between Puget Sound's water circulation and the amount of snow pack (and most likely glacier mass balance) in the Cascade Mountains. Ebbesmeyer et al. (1989) characterized Puget Sound's water circulation on a decade scale by two climate states that are ultimately linked to the amount of freshwater runoff from Cascade rivers. The amount of runoff is dependent on the amount of winter snow pack, which in turn is dependent on the location of the winter Aleutian low pressure center in the North Pacific. The position of the Aleutian Low oscillates on a decade scale that shows a preference for a position closer to Canada or a position closer to Asia. When the Aleutian Low moves eastward, closer to Canada, storm winds become less frequent in the Gulf of Alaska and the Pacific Northwest. Therefore, smaller amounts of precipitable water are available to the Cascades, there is less drainage into the Strait of Juan de Fuca, a density difference is increased across the entrance sill at Admiralty Inlet, and the fastest fjord basin currents occur with inflow at the bottom.

In evaluating the findings of these studies in terms of the Hanford Site, the location of the winter Aleutian Low pressure and the position of the winter storm track should affect the amount of runoff of the Columbia and Yakima Rivers and possibly the amount of winter precipitation that would be recorded locally. Past (and potential) changes in the route, frequency, or strength of storms that would affect the snow pack and mass balance of alpine glaciers of the Cascade Mountains and how these changes also might affect the amount and type of precipitation falling in the Hanford Site region will be determined.

When changes on a decadal scale were investigated for the Hanford Site region, the following findings were obtained. As partly described above, the current climate of southeastern Washington is characterized by relatively cold and wet winters with a secondary spring precipitation maximum (Stone et al. 1983; Ruffner and Bair 1977). On a decadal scale, however, precipitation and temperature patterns have tended to alternate between those that are more continental-like (i.e., similar to Missoula, Montana, with very cold winters and a spring precipitation maximum) and those of a more equable coastal area (i.e., similar to Seattle, Washington, with mild winters and a winter precipitation maximum) (Coatley 1979; Balling and Lawson 1982; Heermann et al. 1971). In the northwestern United States, lowland, treeless areas with a spring precipitation maximum usually are characterized by relatively shallowrooted grasses, whereas areas with a winter precipitation maximum are characterized by more deeply rooted shrubs such as sagebrush (Daubenmire 1970; Risser et a1. 1981). Such patterns of change are important because fossil pollen analyses suggest that an alternating dominance between grass and sagebrush has occurred in eastern Washington in the past. These may provide clues to the potential direction of climatic changes resulting from climatic cycles or as a result of the "greenhouse effect" (Schneider 1989).

In a document titled, A Warm and Wet Little Climatic Optimum and a Cold and Dry Little Ice Age in the Southern Rocky Mountains, U.S.A, Petersen (1992) 
describes a particularly well-documented case study of climate change in the southwestern United States during the 1.ast 2,000 years. Although this study is more applicable to the development of protective barriers at the U.S. Department of Energy's Monticello (Utah) Remedial Action Project for uranium mill tailings, it provides a test case to be compared and contrasted with the climate change history being developed for the Pasco Basin and surrounding regions. Climate change cannot be studied in isolation, but must be considered in both continental and global contexts.

2.3.2.2 Holocene Paleoclimate Literature. Detailed paleoecological and paleoclimatic studies assume increased importance as modern science attempts to predict the impact of global climate change and assess the long-term performance capabilities of hazardous and nuclear waste facilities. This subtask summarizes and synthesizes existing evidence for climatic and ecological change in the Columbia Basin of northwestern America for the last 10,000 to 13,000 years. Inferences based on glacial and fluvial geomorphology, cave and lacustrine sedimentation patterns, palynology, fossil timberlines, subfossil paleontology, and stable isotope study of iniland lakes are integrated into a detailed record of environmental change. Findings identify a terminal Pleistocene environment kept cool and dry by masses of ice and glacial meltwater, supporting a mosaic of now-allopatric plant and animal communities. This was followed between 10,000 and 8,500 years ago by a period of warmer-than-modern summers, colder-than-modern winters, and low but springdominant precipitation, supporting extensive grassiands and the faunas associated with them.

The summer and winter seasons were both relatively warm as of 8,000 years ago, and precipitation was at least 33 percent below modern levels. This climate pattern resulted in reduced stream flows with late spring flow maxima and extensive development of shrub-steppe vegetation throughout most of the region. Climate cooled but remained dry between 5,400 and 4,500 years ago, then underwent a period of transition to wetter, cooler conditions between 4,500 and 3,900 years ago. Rivers flooded frequently and forests expanded into steppe zones. From 3,900 until 2,400 years ago, the climate was c001 in summer and cold in winter, with winter-dominant precipitation at least 30 percent above modern levels. Alpine glaciers underwent the first recorded synchronous advance of the Holocene. Rivers stabilized and their peak flows were delayed into midsummer; steppe vegetation increased in density as subalpine and probably mountain forests expanded beyond modern margins. Warmer, drier conditions returned between 2,400 and 2,000 years ago, reducing vegetation density and bringing a renewal of severe flooding. Climate then improved somewhat, and modern climates were established. The Little Ice Age, a) though evident in alpine cirques, had little apparent effect on regional environments except for a slight drying around 550 years ago. Although this synthesis is detailed, data for important geographic areas are lacking, and most paleoclimatic variables cannot yet be quantified with precision.

In an article titled, "Potential Impacts of Global Climate Change on Pacific Northwest Spring Chinook Salmon (Oncorhynchus tshawytscha): An Exploratory Case Study," Chatters et al. (1991) use a computer model developed by the Northwest Power Planning Council to aid in its salmon enhancement plan of the Council's Fish and Wildi ife Program. Chatters et al. (1991) investigate impact of global warming on the production of spring chinook salmon in the Yakima subbasin of the Columbia River System by simulating the 
conditions inferred from the following field data to have existed between 6,000 and 8,000 years ago.

- Stream flows were less than 70 percent modern.

- Many small, low-elevation, perennial streams became intermittent (dry during part of the year).

- Streams had finer bed loads (greater sedimentation).

- Water temperatures were higher.

- The spring peak flow (freshest) ended 3 to 4 weeks earlier than it does today.

Such conditions would be expected to be produced by a climate that was warmer than that of today, with less precipitation and with a higher percentage of annual precipitation falling as winter rain. Such changes of climatic conditions, if they were to happen, would be important to consider when modeling the protective barrier and assessing its performance.

2.3.2.3 Late Quaternary Paleoclimate Literature. The focus of this i iterature search is on cl imatic records primarily for the last 200,000 years because of the paucity of older records. All five periods of climatic extreme identified to be the focus of study existed within this time period. According to the Milankovitch theory, the Pleistocene ice ages were caused primarily by changes in the seasonal distribution of incoming radiation associated with orbit variations. During the last 800,000 years and possibly as long as 2,000,000 years ago, the Earth has experienced a number of glacial cycles, each lasting about 100,000 years with a 10,000-year-long interglacial period (Hays et al. 1976; Kukla 1981; Berger et al. 1984). The 1ast interglacial/glacial cycle started with a 10,000-year-long interglacial period (deep sea core oxygen isotope stage $5 \mathrm{e}$ ) about 125,000 years ago, which was immediately followed by a rapid growth of global ice sheets beginning at 115,000 years ago.

Glacial climate dominated the Earth until about 12,000 years ago when continental ice retreated from its most southern extent into what is now the state of Washington. No vegetation on Earth escaped the repeated stress of these climates and interglacial adjustments, and the Pasco Basin of southcentral Washington is no exception. With each glacial cycle, the species displaced by climate, ice, water, and competition responded through growth form, migration, or selection, or faced local extinction. The geophysical historical evidence, suggests that the Earth is cycling into the next glacial period (Imbrie and Imbrie 1980; Berger 1981; Berger et a1. 1984). Important questions include the timing and magnitude of natural climate change in the Pasco Basin and exploration of other possible confounding effects.

More evidence is being amassed to show that at particular times, climate change seems to have occurred abruptly (Berger and Labeyrie 1987). For example, during the extreme of the full glacial cycle about 18,000 years ago, Canada was covered with ice. Temperatures during the full glacial were about 2 to $5^{\circ} \mathrm{C}$ colder than present (projections of temperature increase with the greenhouse effect is approaching that same magnitude of change, but it is to 
occur in as little as 100 years). As the globe recovered from the height of the last glacial period, temperatures began warming rapidly and in some quarters reached temperatures close to modern temperatures about 12,000 years ago. However, about 11,000 years ago, one theory (e.g., Berger and Labeyrie 1987) suggests that the Laurentide Ice Sheet had retreated far enough into Canada that the major drainage of glacial melt water could be shifted from the Mississippi drainage to that of the Saint Lawrence River. As a result of this change in drainage, a large pulse of freshwater was injected into the North Atlantic. Because the freshwater is lighter than salt water and has a higher freezing point, the freshwater remained at the surface without mixing and froze. This freshwater sea ice spread across the North Atlantic essentially putting a lid on the entire North Atlantic and effectively cutting off a critical source of heat from the ocean, and Europe and eastern North America were thrown into a short-lived period of glacial climate (termed the 'Younger Dryas' in Europe) almost as severe as the one from which they had emerged. As the continental ice continued to recede towards Hudson Bay, the amount of freshwater from the Saint Lawrence River was sharply curtailed, the freshwater sea ice could not be sustained, and the North Atlantic region recovered from the Younger Dryas ice age.

The study of rapid change, like that which occurred with the Younger Dryas, demonstrates how an earth-born mechanism (the change in the route and amount of melt water) can drastically influence climate. The marine record of climatic change indicates a progressive build up of continental ice sheets from the previous interglacial period through a glacial maximum. However, two recent studies in the western United States suggest that the movement into and out of a glacial climate may be quite abrupt. Phillips et al. (1990a) present repeated evidence for abrupt interglacial/glacial transition in the 1.4-million-year water balance record from Searles Lake, California. They indicate that the lengthy Searles Lake record can be correlated precisely with the marine record through radiometric dating. However, the Searles record, rather than showing a "sawtooth" pattern of glacial cycles characterized by gradually increasing ice volumes followed by very rapid ice volume decrease, shows lake surface as increases at the beginning of glaciations that are almost as rapid as the declines at the glacial terminations. They note that this may be a more accurate reflection of continental climate than the marine record, which may be controlled by the slow dynamics of continental ice sheet formation.

A second paper by Phillips et al. (1990b) reinforces the conclusions of the first (Phillips et al. 1990a). These workers see a rapid response of mountain glaciers to global climate changes as indicated by $\mathrm{Cl}-36$ ages of the glacial moraines in the Sierra Nevada. Phillips et al. (1990b) draws this conclusion because moraines as large as the ones produced shortly before 18,000 years ago are being dated by $\mathrm{Cl}-36$ to 115,000 years ago, the time immediately following the last interglacial (marine stage $5 \mathrm{e}$, which dates 125,000 to 115,000 years ago). This glacial record suggests that the transition into an ice age may be rapid, and small mountain glaciers are able to respond more quickly than the slow buildup of continental ice shown in the marine record.

Such studies suggest that global climate change driven by slow changes in orbital parameters may be nonlinear in nature with feedback mechanisms that push the system toward one state or the other, either glacial or nonglacial, 
and that transition from one state to the other may be rapid. These observations have important implications for the Barrier $\mathrm{Cl}$ imate Task. It has been more than 10,000 years since the last full glacial period, and because of the patterns existing for at least the last 800,000 years, it could be that the Earth is due to move back into a glacial climate. However, Winograd et al. (1992) has questioned the regular cyclic timing use in part to date the pace of the ice ages by using a wel1-dated and uninterrupted 500,000year paleotemperature record contained in ${ }^{18} 0$ concentrations in calcite deposits below the water table in a Nevada crevasse called Devils Hole. Rather than a steady beat of an interglacial-and-ice-age lasting a combined 110,000 years, as predicted by celestial mechanics, Winograd et a1. (1992) found that beginning at 420,000 years ago the interglacial-and-ice-age had increasing lengths of 79,$000 ; 85,000 ; 113,000$; and finally 128,000 years, providing an aperiodic swing to the climate cycle. The implication Winograd et al. (1992) sees for waste isolation is that the present interglacial may last another 10,000 years, and continental glacial ice may reach its maximum extent back into the northern United States within the next 100,000 years.

In view of these and other studies, the change to a full glacial climate in the future could be longer or more rapid than previously thought. To be safe the performance assessment of the barriers to potential climatic change should include a scenario encompassing the conditions found in a full glacial climate, and the probability assigned to that occurrence may be either higher or lower than it would have been.

In a document titled, Modern and Pleistocene Climatic Patterns in the West, which was written as an overview chapter to be included in a book dealing with the western biogeography, Petersen (1991) reviews the important features of the general atmospheric circulation patterns that effect the western United States, describes the impact of continental geography on climate, illustrates the effects of mountains on general circulation, and details the rapid reorganization of the atmosphere with changing seasons. Petersen (1991) looked in detail at the climatic patterns in the west, contrasting mountain climates with that of desert climates. Finally, the author describes the vast changes that took place during the height of pleistocene climate in the western United States as contrasted with the present. Such contexts are important in attempting to understand the underlying driving mechanisms for potential climate change in the Pasco Basin.

2.3.2.4 Flood Records. The Hanford Site region has been affected by past catastrophic flooding, and a large body of 1 iterature has been devoted specifically to that topic. The synthesis of the literature on flood histories will compile hydrographs of the historic Columbia River, will compile evidence for estimates of the magnitude of Holocene floods, and will search information on Scabland Floods and later, glacial flooding to gain estimates of the magnitude and climatic controls on catastrophic floods that have scoured this region. Nothing harsher has been done on this subtask thus far.

2.3.2.5 Global Climate Modeling. A literature review will be conducted of Global Circulation Model experiments covering the ice age, doubled carbon dioxide climatic conditions, and the other targeted periods mentioned previously focusing on the Pacific Northwest. Although large uncertainties in our knowledge of climate exist, many climatologists believe that future 
natural climates will differ significantly from those of today (Berger et al. 1984). However, human activity apparently is rivaling nature's ability to produce climatic change as judged by the potential impact of increasing carbon dioxide and other trace gasses in the atmosphere (Hansen et al. 1981; Schneider 1989). The cycle into the next ice age may be confounded by the steady contribution to the atmospheric burden of carbon dioxide and other trace gases, produced largely through fossil fuel use and possibly through deforestation. There is a growing worldwide concern that this "greenhouse effect" will lead to global warming without precedent in human history in as few as the next 50 years. The potential greenhouse effect, which is possibly the most important consideration for the next 1,000 years, as well as the next glacial period suggest that the next 10,000 years in the Pasco Basin could have climate extremes that may affect the performance of the protective barrier. Identification of those potential extremes is important for the proper barrier design to provide assurance that the barriers will function for periods of time up to 10,000 years without maintenance.

In support of this subtask, a number of literature references have been collected, and Westinghouse Hanford personnel attended the international Chapman Conference on Hydrologic Aspects of Global Climate Change at Lake Chelan, Washington (June 12-14, 1990) to learn about the state-of-the-art status of computer modeling of global climates and regional climates for the Pacific Northwest.

\subsection{TASK 3: POLLEN AND LAKE SEDIMENT STUDIES}

\subsubsection{Purpose}

The purpose of this task is to collect, date, and analyze fossil pollen and other lake sediment data obtained from long cores to refine further the developing climate histor, of the Pasco Basin region and provide more location-specific climatic information on periods of climatic extreme identified for this study plan. Specifically, two subtasks have been identified to accomplish the objective of this task. Subtasks are to develop (1) a transect of pollen sites across the scablands of the central Columbia Basin, and (2) a full-glacial pollen record from Carp Lake, Goldendale, Washington. Subtask 1 is designed to generate data that will refine estimates of change in climatic conditions in the central Columbia Basin that result from Task 2, by studying lacustrine sediments from four lake basins. These lakes, Williams (near Cheney, Washington), Wildcat (near Hooper, Washington), Sulphur (near Connell, Washington), and Badlands (near Benton City, Washington) span the steppe zone of eastern Washington and straddle the Hanford Site and, thus, are expected to provide detailed information on the distributions of vegetation types and levels of groundwater in the Pasco Basin and vicinity.

\subsubsection{Accomplishments}

2.4.2.1 Transect of Pollen Sites across the Scabland of the Central Columbia Basin. During FY 1990, a subcontract was established with Dr. Peter J. Mehringer of Washington State University to conduct the analyses of this 
subtask. Work was directed at three of the pollen sites mentioned previously. Dr. Mehringer previously had obtained sediment cores from Wildcat and Williams lakes, but sampling and analysis was incomplete (see Davis et al. 1977; Mehringer 1985). No core was available from the deeper portions of Suiphur Lake.

An opportunity to review the results of Subtask 3.1 was provided in FY 1991 at the ParkNet-sponsored workshop (June 19-21), "Past Rates of Ecological Change," coordinated by J. C. Chatters and held at PNL under the auspices of the Environmental Sciences Division Office of Health and Environmental Research, Office of Energy Research, U.S. Department of Energy Headquarters, Washington, D.C. Participants included those from PNL, Westinghouse Hanford, Washington State University, tha Idaho National Engineering Laborztory, and the U.S. Geological Survey - Denver.

Wiidcat Lake--The Wildcat Lake analysis concentrated on the pre-7,000-year-old sediments and the integration of resultant data with data from younger portions of the core. The product will be a complete analysis of a scabland lake in the modern steppe zone, which has not been accomplished yet. In al1, more than 120 samples were extracted, and 70 of these were analyzed for pollen, spores, and diatoms. Special attention was paid to the late glacial and glacial-Holocene transitions, which were unexpectedly encountered. Five radiocarbon samples and three volcanic ashes were submitted for anaiysis and will be used to refine the early chronology of sediments.

Hillians Lake--For Williams Lake, which was studied previously by Nickmann (1979), work focused on sediments from the late glacial and early Holocene, with spacial attention given to the transition between the two periods. Sediments were sampled at close intervals to obtain a detailed record of the process of change from glacial to interglacial climates. More than 80 sample's were extracted, of which 40 were analyzed, a large proportion of them from the period dating between 11,000 and 9,000 years ago. Four radiocarbon samples were submitted to refine the dating of this important period of climatic change.

Sulphur Lake--Studies at Sulphur Lake were directed at obtaining sediment of full glacial age, along with younger sediments that could provide insights into water level changes in the Holocene. A core was first obtained from late-Holocene sediments using a modified Livingstone sampler (Deevey 1965). As anticipated, hand coring could not proceed past $8 \mathrm{~m}$ below the sediment surface because of the existence of a band of redeposited Mt. Mazama volcanic ash (dated between 6,850 years and 5,400 years ago). A drilling rig was brought in to auger through this ash arid to place a casing, below which the coring could continue. Holes were augured and cased to $14 \mathrm{~m}$ but were found to end above the base of the ash. The result was that 110 late glacial core was obtained. A geophysical survey is being conducted to generate a profile of the lake bottom and to measure the depth of the volcanic ash layer. The coring effor: can continue in FY 1993 with a greater chance of success. The core of jounger sediments has been described, and four volcanic ash layers and three radiocarbon samples have been submitted for analysis.

Analysis of Pollen from Williams and Wildcat Lakes--The pollen analysis provided very interesting resuits, showing that climatic changes associated with the end of the last glaciation were consistently at least as rapid, 
sometimes more rapid, than those predicted to result from the buildup of greenhouse gases. Sulphur Lake sediments postdating the Mt. Mazama ash layer had a banded character that may have resulted from rapidly fluctuating water levels, so this lake may be an especially good monitor of groundwater levels in the area just east of the Hanford Site.

Several particularly exciting findings were obtained from Wildcat Lake. The sediments, formerly thought to be no older than 10,000 years, were shown to date back nearly 13,000 years, as demonstrated by a radiocarbon date of 12,700 years from above the base of the sediments and the existence of volcanic ash layers suspected to be from Glacier Peak and Mount St. Helens (probably layer $\mathrm{J}$ ). The late glacial pollen assemblage was dominated by sagebrush, with high counts of spruce and fir and the frequent occurrence of nonarboreal pollen types uncommon in the steppe today (e.g., Caryophylaceae). This was a shrub community much like that indicated by many other pollen records of this age. What makes it most interesting is the speed with which this community transformed into a modern steppe, sometime between 10,000 to 10,500 years ago. The transition occurred within a few centimeters of core, certainly within less than 100 years.

The Williams Lake record exhibits a similar transition, but in more detail and extended over a longer period. This record also begins with a high frequency of sagebrush pollen, followed by a brief sagebrush/pine zone, then shifting rapidly, first to grass and pine, then to grass only. The last two changes occur within the span of time required to deposit $0.50 \mathrm{~cm}$ of core (no more than 1 or 2 decades), yet the changes indicate a marked change in local climate. Two important observations come from these findings: (1) climate change in the absence of human intervention can be remarkably swift and (2) vegetation response to such changes in the Columbia Basin and its surroundings also has been rapid.

When these analyses have been completed, it will be possible to generate more detailed scenarios of climate and the processes of climatic and plant community change in the Hanford Site vicinity. Sulphur Lake studies, if successful, are expected to add to the detail on periods of change, provide needed data on the climate of the full $\mathrm{glacial}$, and provide a detailed record of groundwater levels in the Columbia Basin for up to 20,000 years.

\subsubsection{Full Glacial Pollen Record from Carp Lake, Goldendale, Washington.} The second subtask is a coring Carp Lake, southcentral Washington. Golder Associates Incorporated (GAI) was under contract to Westinghouse Hanford to core Carp Lake, $11 \mathrm{~km}$ north of Goldendale, Washington. Carp Lake has been cored previousiy by Cathy Whitlock (Barnosky 1985) and was shown to have a record that extends at least 33,000 years and brackets the period of maximum full glacial conditions, which date to approximately 18,000 years ago. A geophysical survey of the bottom of Carp Lake was performed on August 28, 1990 , by Williamson and Associates, Seattle, to locate the deepest section of Carp Lake. The lake was covered with lily pads that contributed the inability to use a bubble pulser seismic profiling system. A ground-penetrating radar survey was used but it has a depth-penetration limit that extended only down to $4.5 \mathrm{~m}$ and indicated that the sediments layering across the lake are continuous. Although the results were less than predicted, the results 
complement 'iathy Whitlock's (Barnosky 1985) earlier sediment log that was obtained from corings done a few years ago, and both were used to make a selection of the best location to core.

The lake coring operation began on September 14, 1990, with the anchoring of a raft platform in the middle of the 2-m-deep, 25-acre lake located in a late Pliocene/early Pleistocene extinct volcanic crater. A modified Livingstone 5-cm-dia. piston corer, driven by a hand-operated roll jack has been successful in recovering about $20 \mathrm{~m}$ of lake sediment from a cased hole in the center of the platform. The age of a $15-\mathrm{cm}$ volcanic ash layer at $8-\mathrm{m}$ depth is known to have been formed about 33,000 years ago based on the earlier coring efforts at the lake (Barnosky 1985). This gives a deposition rate of 4,000 years $/ \mathrm{m}$ and suggests that the age of the recovered sediments are at least the last 75,000 years and because of sediment compaction could have dated back to 125,000 years. Statistically it is desirable to have a period of record at least 10 times the length of the period to predicted; therefore, a longer climate record obtained from Carp Lake will create more confidence in predictions about natural climate change for the Hanford Site region based on that record. Additional contracts have been put in place with GAI to sample the core, characterize the sediment, submit radiocarbon samples for dating and volcanic ash samples for identification, to process the pollen samples and mount on microscope slides, and finally to analyze and report the results by JuTy 1, 1993.

\subsection{TASK 4: FLUVIAL SEDIMENT AND GROUNDWATER STUDIES}

Task 4 focuses on evidence of climatic change from fluvial sediment or groundwater studies. This task has two subtasks, one concerning fluvial indicators of flood history (Section 2.5.1) and a feasibility study (Section 2.5.2) for using groundwater dates to infer climatic change.

\subsubsection{Fluvial Indicators}

2.5.1.1 Purpose. This task will assess the potential for Columbia River and glacial outburst floods to inundate and erode protective barriers located at lower elevations of the Hanford Site and can be used in conjunction with paleoclimatic records to assess the effects of climatic conditions on the magnitude of flood hazards.

2.5.1.2 Accomplishments. Development of the study plan section for this was the main activity undertaken for this task. In an article titled, "Response of the Columbia River Fluvial System to Holocene Climatic Change," Chatters and Hoover (1992) used a well-dated sequence of floodplain development in the Wells Reservoir region of the upper Columbia River near Okanogan, Washington, to compare to the paleoenvironmental history of the Columbia River Basin. An understanding of the response of fluvial system to past climate changes is useful for predicting its response to future shifts in temperature and precipitation. Results of this comparison indicate that episodes of aggradation (sediment deposition), which occurred approximately 9,000 to $8,000,7,000$ to $6,500,4,400$ to 3,900 , and 2,400 to 1,800 years ago, coincided with climatic transitions that shared certain characteristics. The inferred climates associated with aggradation had at least moderate rates of 
precipitation that occurred mainly in the winter coupled with moderate winter temperatures. Such conditions would have resulted in the buildup of snowpack and a high frequency of rain-on-snow events. The warming and precipitation increases predicted for the Pacific Northwest under most carbon-dioxidedoubling scenarios are likely to repeat these conditions and be important considerations in modeling protective barrier performance.

\subsubsection{Feasibility Study for Episodic Groundwater Recharge}

2.5.2.1 Purpose. In a study of groundwater in eastern Washington, Silar (1969) obtained 43 radiocarbon dates on dissolved carbon dioxide from confined aquifers that lie between basalt strata. Preliminary reanalysis of these dates and their geographic distributions has shown that, rather than exhibiting the expected inverse exponential frequency distribution with age, the dates exhibit strong modalities that correlate with climatic periods recognized in the Holocene. Although the number of dates is small, it is indicative of the potential of water dating for understanding the relationship between climate and groundwater recharge in the region around the Hanford site. Additionally, because meteoric water probably will percolate from the surface into the vadose zone early in the year--before evaporation becomes a significant influence--isotopic composition of dissolved oxygen in groundwater should reflect the composition of the precipitation from which it was derived (Eicher and Siegenthaler 1976; Stuiver 1970). The isotopic composition of this precipitation is directly related to air temperature (Dansgaard 1964). Because the majority of precipitation in this region falls in winter--and the primary source of groundwater is winter precipitation--the oxygen isotope composition of groundwater should be useful as a measure of winter temperature (which is not available from any other data source). This task will explore the feasibility of radiocarbon and oxygen isotope assay of confined groundwater in and around the Pasco Basin as means for studying recharge in relation to climate and winter temperatures, respectively. If the approach proves feasible for one or both applications, the task will be expanded into a full-scale study that will contribute significantly to the understanding of the impact of climatic scenarios on the infiltration of water into waste forms.

2.5.2.2 Accomplishments. Groundwater ages have been compared with the results of the synthesis of Holocene Paleoclimate literature

(Section 2.3.2.2). Results indicate that groundwater derives only from periods when pollen data indicate precipitation fell largely in the winter. Cool periods, such as between 2,500 to 4,000 years ago and after 1,000 years ago, account for the vast majority of groundwater in the Columbia Basin. Most water dates to 3,000 to 4,000 years ago (circa 1200 to $2500 \mathrm{BC}$ ), which is believed to be one of the coldest, wettest periods of the Holocene locally (Chatters and Hoover 1992).

\subsection{TASK 5: TERRESTRIAL SEDIMENT STUDIES}

This task focuses on terrestrial sediment studies and includes two subtasks. Subtask 5.1 is a study of eolian processes and their relationship to climatic conditions of the Hanford Site. Subtask 5.2 is the study of 
WHC-EP-0644

paleontological collections from loess deposits of Pleistocene age, which will be conducted only in the event that pollen and lake sediment studies fail to adequately characterize full-glacial climatic conditions.

\subsubsection{Studies of Eolian Processes}

2.6.1.1 Purpose. A variable that is particularly important for understanding the impact of climatic states on the performance of protective barriers is the influence of climate on surface winds. The direction and velocity of surface winds flowing over sediment source areas (also partially controlled by climate) affect patterns of wind erosion and deposition (collectively referred to here as eolian processes). Removal of fine sediment on protective barriers or sediment deposition on barrier surfaces may impact soil water balance, thereby affecting the barrier's ability to prevent dissolution and transport of waste materials.

This subtask (subcontracted to Dr. David Gaylord, Washington State University) studies the relationship between eolian processes and climatic conditions during the postglacial period $(10,000$ years to 13,000 years ago) on and around the Hanford Site. This subtask consists of three phases. Phase 1 will characterize the eolian systems and eolian sediment chronology on the Hanford Site by (1) collating and analyzing existing meteorological and dune-distribution data to clarify the link between climate and eolian processes and (2) outlining a sequence of dune formation and stabilization intervals on the Hanford Site during the postglacial period. Phase 2 will conduct studies of regional terrain, map and date dune formation episodes on a regional scale, and reconstruct past wind flow patterns. Phase 3 will interpret the 1 ink between Holocene climatic conditions and eolian erosion and sedimentation. The results can be used in conjunction with future climate models, past climatic scenarios, and wind tunnel experiments studied by other program tasks to estimate the likelihood for extensive dune formation on the barriers and wind erosion acting on the barriers.

2.6.1.2 Accomplishments. Research involving the characterization of eolian systems and eolian chronology at the Hanford Site (Phase I) has been initiated, and all of it has produced data that currently are being analyzed. Research has involved (1) assessing aerial photography and location of appropriate eolian sample locales, (2) performing trench studies and sampling eolian deposits, (3) conducting reconnaissance studies for dune deposits containing datable volcanic ash and archaeological sites, (4) analyzing texture and composition of eolian samples, and (5) locating, describing, and sampling Holocene-aged alluvial and alluvial/eolian sediments in the Dry Creek Canyon, along the "horn" of the Yakima River and on the northeastern flanks of Rattlesnake Mountain.

Air Photo Assessment and Interpretation--Air photographs were used (1) to produce an eolian geomorphic base map in conjunction with pre-existing geologic and geomorphic maps, and (2) to determine rates of migration, morphologic changes, and character of airflow-terrain interactions of selected sand dunes during the last approximately 40 years. The eolian geomorphic base map was used to develop the initial FY 1990 sitewide sampling program discussed below. 
A stereoplotter and computer enhancement equipment housed at the University of Wyoming were used to plot precisely the area, shape, and height of nearly 36 dunes located along the southern margin of the main concentration of active Hanford Site sand dunes for four different times: 1948, 1965, 1977 , and 1984. Detailed examination of these dunes has provided data needed (1) to characterize the modern eolian system at the Hanford Site, and (2) to evaluate the range of eolian activity and response times of eolian activity to climatic and geologic variables, including precipitation, temperature, wind speed, and source material availability. Of course, historic land use also must be considered. Efforts are currently underway to interpret these data.

Eolian Trench Studies and Sampling--Test sites occupied during FY 1990 studies will permit a broad understanding of the distribution and character of eolian-generated sediments that accumulated at and near the Hanford Site. Ninety-seven test sites were occupied during FY 1990. At 43 of the test sites, 1.0- to 1.2-m-deep hand-dug trenches were excavated. The stratigraphy of these hand-dug trenches were sketched, primary sedimentary structure orientations were determined, and strata were sampled. Data from each trench are being used to derive the site-specific eolian depositional and erosional histories that will be integrated into an assessment of surficial eolian/ climatic development at the Hanford Site.

Textural and Compositional Analysis of Eolian Samples--Forty-eight sediment samples have been taken on a grid pattern from southerly portions of the Hanford Site. These samples have been analyzed texturally (using sieves). Textural and mineralogic analyses of selected dune and source-area samples currently are underway. Research into the relationship between modern airflow (anemometer) data and the eolian textural distributions is ongoing.

Ash and Archaeological Reconnaissance Field Studies--A portion of this year's field effort was dedicated to locating chronologically distinctive markers, including ash beds, archaeological sites, and radiocarbon datable objects within eolian and (locally) fluvial deposits. Location and integration of such chronologically distinctive markers is essential to calibrating the timing of eolian/climatic variations at the Hanford Site. Eolian deposits containing Mt. Mazama ash discernible from surface exposures were relatively scarce. Five eolian localities and one fluvial locality (along Dry Creek) containing volcanic ash were trenched, described, and sampled. Grant Smith, Washington State University, has written his Master's thesis on the results of this study. Only one archaeological site, the bison kill site, was located in eolian (dune) deposits. This test site was extensively trenched, described, and sampled.

The provenance of the eolian sediments reflects overall dispersal patterns away from source areas. Three potential source localities were sampled and described. These included (1) fluvial sediments exposed along Dry Creek, (2) alluvial sediments along the northeastern flanks of Rattlesnake Mountain, and (3) fluvial/eolian sediments exposed near the horn of the Yakima River. The Dry Creek area was examined most extensively and resulted in six measured 8- to 11-m-thick stratigraphic sections that contain interstratified fluvial strata, volcanic ash, and soil horizons. Eight charcoal samples were collected from these strata to constrain chronologically the sedimentary sequence. Numerous sediment samples were collected from this area, and 
WHC-EP-0644

10 other samples were obtained from Rattlesnake Mountain and Yakima River localities. These samples will be texturally and compositionally analyzed for comparison with downwind samples.

Air Photo Interpretation--Findings from the analysis of historical and recent air photographs indicate three things. First, individual active dunes in the limited area of study have both increased and decreased in size and area during the last 40 years. In general, there has been an apparent trend toward increased stability (decrease in size and area of individual active dunes) during this time. The cause(s) of this are under investigation. Second, long-term (approximately 40 years) dune migration rates range from approximately 2 to $4 \mathrm{~m} /$ years. Data collected have shown that variable dune migration rates and changes in stabilized and active areas are complex. Research is ongoing into the statistical relationships between the timing and character of this eolian activity and modern (documented) changes in precipitation, temperature, and wind speed. Evaluation of these relationships is essential to the accurate sitewide projection of future eolian/climatic effects. Third, rapid restabilization of the previously stabilized dune surface following a 1984 wildfire suggests that the climatic threshold needed to promote wholesale sitewide sand dune reactivation was not breached for long. The continued documentation of the character of eolian/climatic activity at the Hanford Site will provide further insight into the nature of that climatic threshold.

Eolian Trench Studies and Sampling/Textural and Compositional Analyses--Textural analyses of samples from southern portions of the site show a crude, fining downwind trend from southwest to northeast across the Hanford Site. Concentrations of coarse-grained sediment (mean grain sizes from medium- to course-grained sand) occur on and adjacent to the 200 Areas and near the easternmost flanks of Rattlesnake Mountain. Concentrations of fine-grained sediment (mean grain sizes from fine- to medium-grained sand) occur between the 01d Hanford Townsite and the Washington Public Power Supply System reactors.

Provenance Determination, Detailed Description, and Sampling of Holocene-Aged Fluvial Sediments--Two radiocarbon samples from the Dry Creek locality have been analyzed and returned dates of 9,300 years ago from the base of the sequence and 6,400 years within $3 \mathrm{~m}$ of the surface. These results indicate that fluvial deposition was rapid during the early Holocene, but has slowed substantially since 6,400 years ago. An attempt is being made to determine the relationship between this rapid deposition of source material and eolian sediment deposition on the Hanford Site.

\subsubsection{Faunal Indicators}

2.6.2.1 Purpose. If palynological studies fail to obtain a record of vegetation for the full glacial period $(18,000$ years ago), or the last interglacial period (125,000 years ago), assemblages of small vertebrate fossils will be obtained from the loess deposits in the vicinity of the Pasco Basin to provide the needed data (Rensberger et al 1984). The composition of microfaunal communities is relevant to the characterization of past climate at the Hanford Site because animal community composition correlates with modern vegetation distributions and temperature extremes (Harris and Maser 1984). 
Microfauna, including primarily rodents and reptiles, are short-lived, nonmigratory animals with small home ranges. They are often highly habitat specific, so that individual species are good indicators of vegetation and other environmental characteristics. Microfauna bones are resistant to decay in the neutral to basic soils of arid lands and are readily identifiable to the genus level and usually to the species level. Based on the ecological amplitudes of the various animals found in paleontological collections, and the relative abundance of different species, past environmental conditions can be inferred. The results of analysis are usually consistent with paleoenvironmental reconstructions from other sources.

2.6.2.2 Accomplishments. Development of the study $p$ lan section for this task has been the main activity undertaken thus far.

\subsection{TASK 6: PAST CLIMATE/VEGETATION VARIATIONS}

The purpose of this task is to take the results obtained from Tasks 2 though 5 and integrate them into one comprehensive picture of past climate/ vegetation variations in the Hanford Site region for the Late Quaternary and Holocene with special emphasis on the periods $125,000,18,000,9,000,5,000$, and 3,500 years ago. Development of the study plan section for this task has been the main activity undertaken thus far.

\subsection{TASK 7: FUTURE CLIMATE/VEGETATION PROJECTIONS}

The results obtained from the literature search in Task 2 will be used to make future climate/vegetation projections that take into consideration the potential near-term effect of future greenhouse warming and the longer term effect of cycling into the next ice age. Together with Task 6 , the gathered data for this task will be use do formally document a defensible projection of future climate and vegetation variability. Development of the study plan section for this task has been the main activities undertaken thus far.

\subsection{TASK 8: LOCAL CLIMATE FORECAST MODEL AND TASK 9: MODEL CALIBRATION AND VALIDATION}

Conceptually, the projection of future climate variation in the Hanford Site region will be accomplished through the development of a local climate forecast model that will use Global Climate Model (GCM) experiment results to provide initial bounding conditions. The primary purpose of the local climate modeling effort to provide confidence in estimates of future potential climate change due to the effects of increased carbon dioxide or other anthropogenic gas sources, such as methane or chlorofluorocarbons. Validation and calibration of the local climate model will be accomplished in part through the use of past climate conditions derive from paleoclimate studies. The output from the local climate model then will be used to project future variability in the precipitation and temperature of the Hanford Site region will then be available to aid in barrier performance assessment analyses. Development of the study plan section for this has been the main activity undertaken thus far. 
WHC-EP-0644

\subsection{TASK 10: PROJECTION OF FUTURE CLIMATES}

The purpose of this task is to provide the needed information on potential future climates so the effects of future climatic change can be assessed as it pertains to the disposal of wastes at the Hanford Site. This will aid in development of the barrier design and the demonstration of compliance to regulatory requirements and performance standards. Development of the study plan section for this task has been the main activity undertaken thus far.

\subsection{TASK 11: GENERATION OF WEATHER STATISTICS}

If data from Task 10 do not project specific parameters in enough detail such as mean monthly precipitation, mean monthly temperature, and coefficients of variation for solar radiation, specific weather statistics generation models will be used to estimate these parameters. Development of the study .plan section for this task has been the main activities undertaken thus far.

\subsection{TASK 12: IDENTIFICATION OF SPACIAL ANALOGS OF VEGETATION RESPONSE TO PROJECTED CLIMATES}

The Natural Analogs Task of the Hanford Protective Barriers Program includes a study of the effects of different vegetation types that are likely to develop on barriers under the extremes of climate characterized by the this study plan. Task 12 will provide the criteria, in terms of both climatic conditions and plant community composition, that will be used to select vegetation analog sites. Development of the study plan section for this task has been the main activity undertaken thus far.

\subsection{TASK 13: INPUT CLIMATIC DATA TO BARRIER PERFORMANCE ASSESSMENT}

The purpose of this task is to meet the objectives of the long-term climate change assessment tasks, which include the following.

- Use the past climate, current meteorological conditions, and modeled future global changes to project climatic variability in the Pasco Basin for a variety of time scales into the future.

- Provide information that pertains to the effects of climatic change on the disposal of wastes at the Hanford Site to the other components of the Protective Barrier Development Program so that the barrier can be designed to minimize drainage to meet regulatory requirements and performance standards (as they currently exist or as they evolve).

- Provide information that will be used to test the long-term performance of the barrier to confirm its effectiveness in minimizing drainage that could ultimately lead to movement of radionuclides to the accessible environment. 
Development of the study plan section for this task has been the main activity undertaken thus far.

\subsection{REFERENCES}

Adams, M. R. and N. R. Wing, 1986, Protective Barrier and Warning Marker System Development P7an, RHO-RE-PL-35P, Rockwe11 Hanford Operations, Richland, Washington.

Balling, R. C., Jr., and M. P. Lawson, 1982, "Twentieth Century Changes in Winter Climatic Regions," Climatic Change, Vo1. 4, pp. 57-69.

Barnosky, C. W., 1985, "Late-Quaternary Vegetation in the Southwestern Columbia Basin, Washington," Quaternary Research, Vol. 23, pp. 109-122.

Berger, A. L., 1981, "The Astronomical Theory of Paleoclimates," in A. Berger, (ed), Climatic Variations and Variability: Facts and Theories, D. Reidel Publishing Company, Dordrecht, Holland, pp. 501-525.

Berger, A., J. Imbrie, J. Hays, G. Kukla, and B. Saltzman (eds), 1984, Milankovich and Climate, D. Reidel, Dordrecht, Holland.

Berger, W. H. and L. D. Labeyrie (eds), 1987, Abrupt Climatic Change: Evidence and Implications, D. Reide I, Dordrecht, Holland.

Burbank, D. W., 1982, "Correlations of Climate, Mass Balances, and Glacial Fluctuations at Mount Rainier, Washington, U.S.A., Since 1850," Arctic and Alpine Research, Vol. 14, No. 2, pp. 137-148.

Chatters, J. C., D. A. Neitzel, M. J. Scott, and S. A. Shankle, 1991, "Potential Impacts of Global Climate Change on Pacific Northwest Spring Chinook Salmon (Oncorhynchus tshawytscha): An Exploratory Case Study," The Northwest Environmental Journal, Vol. 7, pp. 71-92.

Chatters, J. C. and K. A. Hoover, 1992, "Response of the Columbia River Fluvial System to Holocene Climatic Change," Quaternary Research, Vol. 37, pp. 42-59.

Coatley, S. M., 1979, "Climate Variability in the Pacific Northwest and its Effect on Stripe Rust Disease of Winter Wheat, "Climatic Change, Vol. 2, pp. 33-51.

Cropper, J. P. and H. C. Fritts, 1986, A 360 Year Temperature and Precipitation Record for the Pasco Basin Derived from Tree Rings, DOE-RL-01830-T46, U.S. Department of Energy, Richland Operations Office, Richl and, Washington.

Dansgaard, W., 1964, "Stable Isotopes in Precipitation," Tellus, Vo1. 16, pp. $436-468$. 
Daubenmire, R., 1970, Steppe Vegetation of Washington, Washington Agricultural Experiment Station, Technical Bulletin 62, Pullman, Washington.

Davis, 0. K., D. A. Kolva, and P. J. Mehringer, 1977, "Pollen Analysis of Wildcat Lake, Whitman County, Washington: The Last 1,000 Years," Northwest Science, Vo1. 51, pp. 13-30.

Deevey, E. W., 1965, Sampling Lake Sediments by the Use of a Livingstone Sampler, in B. Kunnel and D. Raup (eds), Handbook of Paleontological Techniques, Freeman and Company, San Francisco, California, pp. 521-529.

DOE-RL, 1987, Final Environmental Impact Statement for the Disposal of Hanford Defense High-Leve 1, Transuranic, and Tank Waste, DOE/EIS-0113, U.S. Department of Energy, Richiand Operations Office, Richland, Washington.

Ebbesmeyer, C. C., C. A. Coomes, G. A. Cannon, and D. E. Bretschneider, 1989, "Linkage of Ocean and Fjord Dynamics at Decadal Period," in D. H. Peterson (ed), Aspects of Climate Variability in the Pacific and Western Americas, Geophysical Monograph 55, American Geophysical Union, Washington, D.C., Pp. 399 to 417.

Eicher, U. and U. Siegenthaler, 1976, "Palynological and Oxygen Isotope Investigations on Late-Glacial Sediment Cores from Swiss Lakes," Boreas, Vol. 5, Pp. 109-117.

Gramulich, L. J., 1987, "Precipitation Variation in the Pacific Northwest (1675-1975) as Reconstructed from Tree Rings," Annals of the Association of American Geographers, Vol. 77, pp. 19-29.

Hansen, J., D. Johnson, A. Lacis, S. Lebedeff, P. Lee, D. Rind, and G. Russe11, 1981, "Cl imate Impact of Increasing Atmospheric Carbon Dioxide," Science, Vol. 213, pp. 957-966.

Harris, L. D. and C. Maser, 1984, Animal Community Characteristics, in L. D. Harris (ed), The Fragmented Forest: Island Biogeography Theory and the Preservation of Biotic Diversity, University of Chicago Press, Chicago, Illinois, pp. 44-70.

Hays, J. D., J. Imbrie, and N. J., Shackleton, 1976, "Variations in the Earth's Orbit: Pacemakers of the Ice Ages," Science, Vol. 194, pp. 1121-1132.

Heermann, D. F., M. D. Finkner, and E. A. Hiler, 1971, Probability of Sequences of Wet and Dry Days for Eleven Western States and Texas, Colorado State University Experiment Station, Technical Bulletin 117, Fort Collins, Colorado.

Imbrie, J. and J. Z. Imbrie, 1980, "Modeling the Climatic Response to Orbital Variations," Science, Vol. 207, pp. 943-953.

Kukla, G. J., 1981, "Pleistocene Climates on Land," in A. Berger (ed), Climate Variations and Variability: Facts and Theories, D. Reidel Publishing Company, Dordrecht, Holl and, pp. 207-232. 
Mehringer, P. J., Jr., 1985, Late Quaternary Pollen Records from the Interior Pacific Northwest and Northern Great Basin of the United States, in V. M. Bryant, Jr. and R. G. Holloway (eds), Pollen Records of LateQuaternary North American Sediments, American Association of Stratigraphic Association, Dallas, Texas, Pp. 167-189.

Mitchel1, J. M., Jr., 1987, "Climatic Variation, Instrumental Data," in J. E. Oliver and R. W. Fairbridge (eds), The Encyclopedia of Climatology, Van Nostrand Reinhold, New York, Pp. 323-327.

Nickmann, R., 1979, The Palynology of Williams Lake Fen Spokane County, Washington, Unpublished Master's Thesis, Department of Geology, Eastern Washington University, Cheney, Washington.

Petersen, K. L., 1991, Modern and Pleistocene Climatic Patterns in the West, WHC-EP-0523, Westinghouse Hanford Company, Richland, Washington.

Petersen, K. L., 1992, A Warm and Wet Little Climatic Optimum and a Cold and Dry Little Ice Age in the Southern Rocky Mountains, U.S.A., WHC-SA-1382-FP, Westinghouse Hanford Company, Richland, Washington.

Petersen, K. L., J. C. Chatters, and W. J. Waugh, 1992, Long-Term Climate Change Assessment Study Plan for the Hanford Site Permanent Isolation Barrier Development Program, WHC-EP-0569, Westinghouse Hanford Company, Richland, Washington.

Phillips, F. M., A. C. Campbell, R. Roberts, and C. V. Kruger, 1990a, "Abrupt Interglacial/Glacial Transition in the $1.4 \mathrm{Ma}$ Waterbalance Record from Searles Lake, California," American Quaternary Association Program and Abstracts, June 4-6, 1990, University of Waterloo, Waterloo, Ontario, pp. 28.

Phillips, F. M., M. G. Zreda, S. S. Smith, D. Elmore, P. W. Kubik, and P. Sharma, 1990b, "Cosmogenic Chlorine-36 Chronology for Glacial Deposits at Bloody Canyon, Eastern Sierra Nevada," Science, Vol. 248, pp. 1529-1532.

Rensberger, J. M., A. D. Barnosky, and P. Spencer, 1984, Geology and Paleontology of a Pliestocene-to-Holocene Loess Succession, Benton County, Washington, Archaeological and Historical Services Report in Archaeology and History, No. 100-39, Eastern Washington University, Cheney, Washington.

Risser, P. G., E. C. Birney, H. D. Blocker, S. W. May, W. J. Parton, and J. A. Weins, 1981, The True Prairie Ecosystem, Hutchinson Ross Publishing Company, Stroudsburg, Pennsylvania.

Ruffner, J. A. and F. E. Bair (eds), 1977, The Weather Almanac, 2nd edition, Gale Research Company, Book Tower, Detroit, Michigan.

Schneider, S. H., 1989, Global Warming, Sierra Club Books, San Francisco, Washington. 
Silar, J., 1969, Groundwater Structures and Ages in the Eastern Columbia Basin, Washington, College of Engineering Research Division Bulletin 315, Washington State University, Pullman, Washingtun.

Stone, W. A., J. M. Thorp, O. P. Gifford, and D. J. Hoitink, 1983, Climatological Summary for the Hanford Area, PNL-4622, Pacific Northwest Laboratory, Richland, Washington.

Stuiver, M., 1970, "Oxygen and Carbon Isotope Ratios of Fresh Water Carbonates as Climatic Indicators," Journal of Geophysical Research, Vol. 75, pp. 5247-5257.

Winograd, I. J., T. B. Coplen, J. M. Landwehr, A. C. Riggs, K. R. Ludwig, B. J. Szabo, T. P. Kolesar, and M. Revesz, 1992, "Continuous 500,000-Year ci imate Record from Vein Calcite in Devils Hole, Nevada," Science, Vol 258, pp. 255-260. 


\section{DISTRIBUTION}

Number of copies

FOREIGN

1 BRGM - Departement "Environment" BP 6009 45060 ORLEANS CEDEX, FRANCE

M. Barres

1 Department of Geography University of Western Ontario London, Ontario N6A 5C2

Canada

Dr. B. H. Luckman

1 Waste Management Unit British Nuclear Fuels plc Sellafield

Seascale, Cumbria CA201PG ENGLAND

P. Grimwood

1 Institut für Bodenkunde der Universităt Hamburg

Allende-P1atz 2, D-2000 Hamburg 13

Federal Republic of Germany

S. Melchior

1 Intera Information

Technologies

Chiltern House

45 Station Road

Henley-on-Thames

Oxfordshire RG9 IAT

UNITED KINGDOM

G. M. Smith
Number of copies

OFFSITE

2 Agronomy Department Washington State University Pullman, Washington 99164

Dr. A. J. Busacca

Dr. G. S. Campbel1

1 Anasazi Heritage Center Bureau of Land Management 2750.1 Hwy 184

Dolores, Colorado 81323

Document Clerk

1 Archaeological Research Services P.0. Box 701 Virginia City, NV 89440

V. L. C1ay

1 Argonne National Laboratory 9700 South Cass Avenue Argonne, IL 60439

M. J. Steindler

1 Argonne National Laboratory P.0. Box 2528

Idaho Falls, ID 83401

C. S. Abrams

1 Arizona-Sonoran Desert Museum Rt. 9, Box 9

Tucson, Arizona 85743

Dr. T. R. Van Devender

1 Arizona State Museum University of Arizona Tucson, AZ 85721

S. K. Fish 


\section{DISTRIBUTION (cont.)}

Number of copies

\section{OFFSITE}

1 Bandelier National Monument HCR 1, Box 1, Suite 15 Los Alamos, New Mexico 875449702

C. Al1e::

3 Batteile Memorial Institute Project Management Division 505 King Avenule

Columbus, $\mathrm{OH} 3201$

W. A. Carbeiner

W. S. Madia

Technical Library

1 Bureau of Land Management

Moab District

P.0. Box 970

Moab, Utah 84532

B. D. Louthan

1 Bureau of Reclamation MF-750

U.S. Department of Interior 2800 Cottage Way

Sacramento, California 958251298

Dr. G. J. West

3 Bibly Research Center

Northern Arizona University

Box 6013

Flagstaff, Arizona 86011

Dr. L. Agenbroad

Dr. R. S. Anderson

Dr. J. I. Mead

2 Botany and Range Science Department Brigham Young University 401 WIDB

Provo, Utah 84602

Dr. H. H. Hess

Dr. K. T. Harper
Number of copies

\section{OFFSITE}

1 Boulder Laboratory

Geological Survey

U.S. Department of Interior

Box 25046, M.S. 458

Denver Federal Center

Denver, Colorado 80225

Dr. L. Benson

1 Branch of Sedimentary

Processes

U.S. Geological Survey-MS 902

345 Middlefield Road

Menlo Park, California 94025

Dr. G. I. Smith

1 Cascade Earth Sciences. Ltd.

P.0. Box 137

Corbett, OR 97019

S. W. Childs

4 Chem Nuclear Geotech

P.0. Box 14000

Grand Junction, CO 81502

J. Duray

J. Elmer

v. Ponc

W. J. Waugh

2 CIRES

University of Colorado

Campus Box 449

Boulder, Colorado 80309

Dr. R. G. Barry

Dr. M. K. Humfrey

1 Colorado Climate Center Department of Atmospheric Science

Colorado State University

Fort Collins, Colorado 80523

N. J. Doesken 


\section{DISTRIBUTION (cont.)}

Number of copies

OFFSITE

1 Colorado Department of Health Drinking Water Division 4210 E. 11th Avenue Denver, CO 80220

W. Wright

2 Crow Canyon Archaeological Center 23390 County Road K Cortez, CO 81321
R. H. Wilshusen
K. Adams

1 Dames and Moore Suite 108 4220 S. Maryland Park Way Las Vegas. Nevada 89119

Dr. W. G. Spaulding

1 Department of Anthropology Arizona State University Teinpe, Arizona 85281

Dr. J. Schoenwetter

5 Department of Anthropology Washington State University Pullman, Washington 99164

Dr. J. H. Bodley

Dr. G. L. Gamble

Dr. F. A. Hassan

Dr. W. A. Lipe

Dr. P. J. Mehringer

1 Department of Anthropology University of Oregon

Eugene, Oregon 97403

Dr. C. M. Aikens

\section{Number of copies}

\section{OFFSITE}

2 Department of Anthropology University of Colorado Boulder, Colorado 80309-0233

Dr. F. W. Eddy

Dr. P. D. Sheets

1 Department of Atmospheric Science Creighton University Omaha, Nebraska 68178-0110

Dr. A. V. Douglas

1 Department of Biology University of New Mexico Albuquerque, New Mexico 87131

Dr. R. G. Holloway

1 Department of Biological Sciences Northern Arizona University Flagstaff, Arizona 86001

Dr. R. H. Hevly

1 Department of Civil Engineering University of Texas Austin, TX 78712

D. E. Daniel

1 Department of Forest Resources University of Minnesota 115 Green Ha11, NPS/CPSU St. Paul, Minnesota 55108

Dr. K. L. Cole

1 Department of Geography Arizona State University Tempe, Arizona 85287

Dr. P. L. Fall 


\section{DISTRIBUTION (cont.)}

Number of copies

\section{OFFSITE}

2 Department of Geography University of Oregon Eugene, Oregon 97403

Dr. P. J. Bartlein

Dr. C. Whitlock

2 Department of GeographyGeology Geological Survey

U.S. Department of Interior

Box 25046, M.S. 913

Denver Federal Center

Denver, Colorado 80225

Dr. P. E. Carrara

Dr. R. R. Shroba

1 Department of Geology University of New Mexico

Albuquerque, New Mexico 87131

Dr. R. Y. Anderson

1 Department of Geology University of Iowa Iowa City, Iowa 52242

Dr. R. G. Baker

2 Department of Health Radiation Protection Division Airdustrial Park

B1dg. 5, M.S. LE-13

OTympia, WA 98504

Alan Rainey

1 Department of Mechanical

Engineering

New Mexico State University

Box 30001

Las Cruces, NM 88003

R. G. Hills
Number of copies

\section{OFFSITE}

1 Department of Plant and Soil Science 12A Stockbridge Hall University of Massachusetts Amherst, MA 01003

D. Hillel

2 Department of Range Science Utah State University Logan, Utah 84322

Dr. M. M. Caldwel1

Dr. N. E. West

1 Department of Soil and Water Science 429 Shantz Building University of Arizona Tucson, AZ 85721

P. J. Wierenga

1 Department of Soils University of California at Riverside Riverside, CA 92502

W. A. Jury

1 Department of Systematic Ecology

University of Kansas

Lawrence, Kansas 66045

Dr. P. V. Wells

2 Desert Research Institute P.0. Box 60220 Reno, NV 89506

J. T. Ball

S. Tyler 


\section{DISTRIBUTION (cont.)}

Number of copies

\section{OFFSITE}

1 Golder Associates 4104-148th Ave. NE Redmond, WA 98052

Dr. R. L. Burk

1 Division of Earth Sciences University of Nevada, Las Vegas

100 Washington Street, Suite 201

Reno, Nevada 89503

T. Flynn

1 Division of Fuel Materizl Safety

U.S. Nuclear Regulatory Commission

Washington, D.C. 20555

\section{A. T. Clark}

1 Division of Historic

Preservation and Archaeology

123 W. Nye Lane, Room \#208

Capitol Complex

Carson City, Nevada 89710

Dr. E. M. Hattori

12 DOE/Office of Scientific and Technical Information

2 EBASCO

1201 Jadwin

Richland, WA 99352

\section{W. Riggsbee}

R. L. Treat

2 EG\&G Idaho. Inc,

P.0. Box 1625

Idaho Falls, ID 83415-3900

J. E. Conner

K. M. Kostelnik
Number of copies

\section{OFFSITE}

1 Electric Power Research Institute 3412 Hillview Avenue Palo Alto, CA 94304

R. Shaw

1 Environmental Research Laboratory NOAA

325 Broadway

Boulder, Colorado 80303

Dr. H. F. Diaz

2 Environmental Research

Laboratory-Corvalis

Environmental Protection Agency

200 S.W. 35th Street

Corval is, Oregon 97333

Dr. G. A. King

Dr. R. P. Neilson

1 Environmental Sciences

Division, ER-74

Department of Energy - HQ

Office of Health and

Environmental Research

Office of Energy Research

Washington, D.C. 20585

Dr. C. D. Jorgensen

1 Forestry Department University of Washington

Seattle, WA 98195

L. J. Fritschen

1 Geography Department University of Texas at Aust in Austin, TX 78712

Dr. S. A. Hall 


\section{DISTRIBUTION (cont.)}

Number of copies

OFFSITE

1 Geography Department 501 Earth Sciences University of California Berkeley, California 94720

Dr. R. Byrne

1 Geology Department Texas A\&M University College Station, TX 77843

J. A. Gennett

2 Geology Department Washington State University Pullman, Washington 99164

Dr. K. Keller

Dr. D. Gaylord

3 Geosciences Department University of Arizona Bldg. \# 77

Tucson, Arizona 85721

Dr. 0. K. Davis

Dr. P. S. Martin

P. Van de Water

1 Global Climate Change Program Building 203, Room J-159 Argonne National Laboratory 9700 South Cass Avenue Argonne, Illinois 60439

R. A. Reck

1 Goddard Institute for Space Studies 2880 Broadway

New York, New York 10025

Dr. D. H. Rind
Number of copies

\section{OFFSITE}

1 Hazen and Sawyer 4011 W. Chase BTvd. Suite 500 Raleigh, NC 27607

G. N. Richardson

1 High-Level Waste Management Washington State Department of Ecology

Mail Stop PU II

01 ympia, WA 98504

J. Rensel

4 Idaho National Engineering Laboratory

P.0. Box 1625

Idaho Falls, ID 83415

M. A. Knecht

J. B. Sisson

B. B. Russel1

Technical Library

1 Illinois State Water Survey 2204 Griffith Dr. Champaign, Illinois 61820

Dr. W. M. Wendl and

1 In-Situ, Inc. P.0. Box 1 Laramie, WY 82070

C. R. McKee

4 INSTAAR University of Colorado Box 450

Boulder, Colorado 80309-0450

Dr. S. A. Elias

Dr. V. Markgraf

Dr. H. Nichols

Dr. S. K. Short 


\section{DISTRIBUTION (cont.)}

Number of copies

\section{OFFSITE}

1 Intermountain Forest and Range Experiment Station

U.S. Department of

Agriculture

Forest Service

Northern Forest Fire

Laboratory

Drawer G

Missoula, Montana 59806

Dr. S. Arno

1 Jacobs Engineering Group Inc. 2530 Arnold Drive

Martinez, CA 94553

C. Reith

4 Jacobs Engineering Group. Inc.

5301 Central Avenue NE

Suite 1700

Albuquerque, NM 87108
M. Kyl10
N. B. Larson
F. Titus
T. Goering

1 Laboratory of Biomedical and

Environmental Sciences

University of California at

Los Angeles

Los Angeles, CA 90024

E. M. Romney

5 Laboratory of Tree-Ring

Research

University of Arizona

Building \#58

Tucson, Arizona 85721

Dr. J. S. Dean

Dr. H. C. Fritts

Dr. L. J. Grauml ich

Dr. K. K. Hirschboeck

Dr. M. A. Stokes
Number of copies

\section{OFFSITE}

1 Lawrence Livermore National

Laboratory

University of California

P.0. Box 808

Livermore, CA 94550

L. D. Ramspott

1 Lockheed Environmental

Sciences

and Technology Division

870 Kelly Johnson Drive

Las Vegas, NV 89119

K. Snyder

5 Los Alamos National

Laboratory

P. 0. Box 1663

Los Alamos, NM 87545

T. E. Hakonson

J. W. Nyhan

F. Barnes

T. D. Oakley

Charles Harrington

1 Low-Level Radioactive Waste Program

Washington State Department

of Ecology

Mail Stop PV-11

O1ympia, WA 98504

E. M. Carlin

3 Low-Level Radioactive Waste Program

U.S. Geological Survey

Water Resources Division

12201 Sunrise Valley Drive Reston, VA 22092
J. Fisher
P. Stevens
N. Trask 


\section{DISTRIBUTION (cont.)}

Number of copies

OFFSITE

1 Mesa Verde Regional Research Center

P.0. Box 592

Dove Creek, Colorado 81324

Dr. D. A. Breternitz

1 Metcalf and Eddy Consultants, Inc.

P.0. Box 24110

Santa Barbara, CA 93121

L. G. Everett

1 Nature Conservancy

P.0. Box 11486

Salt Lake City, Utah 84147

Dr. N. S. Van Pelt

2 New Mexico State University

Agricultural Experiment Station

Box 3BF

Las Cruces, NM 88003

T. L. Jones

D. M. Briggs

1 NPS-Haleakala National Park P.0. Box 369

Makawao, Maui, Hawaii 96768

Dr. L. L. Loope

3 Oak Ridge National Laboratory P.0. Box Y

Oak Ridge, TN 37830

J. 0. Blomeke

W. D. Burch

R. T. Jubin

1 Oak Ridge National Laboratory P.0. Box 2008

Oak Ridge, TN 37831

G. Suter II
Number of copies

OFFSITE

1 Office of High-Level Nuclear Waste Management Washington State Department of Ecology

Olympia, WA 98504

W. Brewer

1 Paleo Research Laboratories 15485 W. 44th Ave, Suite A Golden, CO 80403

Dr. L. S. Cummings

1 Paleontology and Stratigraphy Branch Geological Survey

U.S. Department of Interior Box 25046, M.S. 919 Denver Federal Center

Denver, Colorado 80225

Dr. R. S. Thompson

4 Sandia National Laboratories

P.0. Box 5800

Albuquerque, NM 87185

R. W. Lunch

E. Webb

R. Sandova?

Technical Library

1 Scripps Inst. of Oceanography A-0224, Univ of CA-San Diego La Jolla, California 920930224

D. Cayan

3 Social Science Center Desert Research Institute P.0. Box 60220

Reno, Nevada 60220

F. M. Nials

Dr. L. C. Pippin

Dr. P. E. Wigand 


\section{DISTRIBUTION (cont.)}

\section{Number of copies}

\section{OFFSITE}

1 Southern California Edison P.0. Box 800 Rosemead, CA 91770

\section{A. A. Eiseewi}

1 Tech Reps. Inc. 5000 Marbel Avenue NE Albuquerque, NM 87110

\section{P. N. Swift}

1 Tree-Ring Laboratory Lamont-Doherty Geol. Observ. Palisades, New York 10964

Dr. G. C. Jacoby

1 University of California Department of Plant and Soil Biology

Berkeley, CA 94720

R. K. Schulz

1 U.S. Army Engineer Waterways Experiment Station $3909 \mathrm{Ha} 1 \mathrm{ls}$ Ferry Ro d Vicksburg, MS 39180-6199

R. D. Bennett

1 U.S. Bureau of Mines Spokane Research Center East Montgomery Spokane, WA 99207
J. 01 son

2 U.S. Department of Energy 785 DOE Place Idaho Falls, ID 83402

0. D. Markham

T. E. Reynolds
Number of copies

\section{OFFSITE}

1 U.S. Department of Energy Savannah River Operations Office

P.0. Box A

Aiken, SC 29801

W. J. Brumley

1 U.S. Department of Energy San Francisco Operations Office 1333 Broadway

Oakl and, CA 94612

F. T. Fong

1 U.S. Department of Energy Oak Ridge Operations Office P.O. BoX E Oak Ridge, TN 37830

M. R. Jugan

1 U.S. Department of Energy West Valley Project Office P.0. Box 191 West Valley, NY 14171

E. Maestas

1 U.S. Department of Energy Albuquerque Operations Office P.0. Box 5400 Aibuquerque, NM 87185

M. Matthews

1 U.S. Department of Energy Morgantown Energy Technology Centar P.0. Box 880 Morgantown, WV 26505

R. C. Letcher 


\section{DISTRIBUTION (cont.)}

Number of copies

OFFSITE

1 U.S. Department of Energy 625 Marion Street, N.E. Salem, OR 97310

L. Frank

2 U.S. Ecology P. 0 . Box 7246 9200 Shelbyville Rd Suite 526 Louisville, KY 40207
R. E. Sauer
D. Lane

1 U.S. Environmental Protection Agency 1200 Sixth Averue Seattle, WA 98101

C. Massimino

1 U.S. Environmental Protection Agency

Office of Radiation Programs (ANR-458)

401 M Street, S.W.

Washington, D.C. 20460

S. Meyers

1 U.S. Geological Survey 345 Middlefield Road-MS 915 Men 10 Park, California 94025

Dr. D. P. Adam

1 U.S. Geological Survey

1675 W. Anklam Road Tucson, Arizona 85745

Dr. J. L. Betancort

1 U.S. Geological Survey

Federal Center Mail Stop 413

Denver, CO 80225

E. P. Weeks
Number of copies

OFFSITE

1 U.S. Geological Survey

M.S. 913

P.0. Box 25046

Denver Federal Center

Denver, CO 80225

J. Whiting

2 U.S. Geological Survey 12201 Sunrise Valley Drive Reston, VA 22092

G. A. Dinwiddie

I. J. Winograd

2 U.S. Nuclear Regulatory $\frac{\text { Commission }}{\text { Division of Engineering }}$ Safety

MS NL-005

Washington, DC 20555

E. O'Donnel1

T. J. Nicholson

1 Ward Center for Mountain

Research

8297 Overl and Road

Ward, Colorado 80481

Dr. J. B. Benedict

2 Washington State Department of Ecology

Mail Stop PV-11

Olympia, WA 98504-8711

C. Cline

R. B. Hibbard

1 Washington State Department of Ecology

7601 W. Clearwater, Suite 102

Kennewick, WA 99336

N. U. Uzimblo 


\section{DISTRIBUTION (cont.)}

Number of copies

\section{OFFSITE}

1 Waste Management Branch

Office of Nuclear Regulatory

Research

U.S. Nuclear Regulatory

Commission

Washington, DC 20555

M. Silberberg

4 West Valley Nuclear Service Company

P.0. Box 191

West Valley, NY 14171
R. R. Borisch
J. Buggy
J. M. Pope
R. A. Thomas

1 Western Regional Climate Center Desert Research Institute P.0. Box 60220

Reno, Nevada 89506-0220

Dr. K. Redmond

2 Westinghouse Idaho Nuclear $\frac{\text { Co. }}{\text { P.0. Box } 4000}$ Idaho Falls, ID 83403

J. R. Berreth

D. A. Knecht

6 Westinghouse Savannah River Company

Aiken, SC 29801

R. G. Baxter

M. D. Boersma

J. G. Giasscock

J. R. Knight

S. McMullen

M. J. Plodinec

C. T. Randall
Number of copies

\section{OFFSITE}

1 White Mesa Institute 295 N 100 W 19-3 B1 anding, Utah 84511

W. Hurst

3 World Data Center - A For Paleoclimatology NOAA Paleoclimatology Program National Geophysical Data Center 325 Broadway E/GC, Boulder, CO 80303
J. Overpeck
D. Anderson
R. Webb

\section{ONSITE}

11 U.S. Department of Energy Richland Field office

G. J. Bracken

A4-02

J. J. Broderick

A7-27

R. D. Freeburg

A5-19

R. E. Gerton

A4-02

J. D. Goodenough

A5-19

A. C. Harris

A5-19

R. D. Izatt

A3-42

C. R. Pasternak

A7 -27

R. K. Stewart

A5-19

D. E. Trader DOE-RL Public Reading Rooml

A5-90

H2-53

5 Environmental Protection Agency - Hanford Project Office

P. R. Beaver

D. A. Faulk

L. E. Gadbois

B5-01

P. S. Innis

B5-01

D. R. Sherwood

B5-01 


\section{DISTRIBUTION (cont.)}

Number of copies

34 Pacific Northwest Laboratory
L. L. Cadwell
P7-54
M. D. Campbe11
K6-77
J. L. Downs
P7-54
M. J. Fayer
K6-77
M. G. Foley
H. D. Freeman
K6-84
G. W. Gee (2)
S. J. Ghan
M. J. Graham
P. C. Hays
C. T. Kincaid
P8-38
$\mathrm{K} 6-77$
K6-08
$\mathrm{K} 6-78$
K6-86
R. R. Kirkham
K6-77
G. V. Last
K6-77
K6-96
M. W. Ligotke
P7-54
S. 0. Link
P7-54
G. P. O'Connor
P7-54
W. T. Pennell
K1-74
W. H. Rickard
P7-54
M. L. Rockhold
K6-77
L. E. Rogers
P7 -54
R. A. Romine
P8-38
M. A. Simmons
P7-54
R. L. Skaggs
S. C. Slate
T. L. Stewart
K6-77
K1-19
K1-51
G. M. Stokes
$\mathrm{K} 1-74$
J. A. Stottlemyre
K6-75
G. P. Streile
$\mathrm{K} 6-77$
M. E. Thiede
P7-54
J. M. Thomas
P7-54
P. Van Voris
$\mathrm{K} 4-12$
W. H. Walters
K6-06
R. E. Wildung

2 U.S. Army Corps of Engineers

$\begin{array}{ll}\text { W. L. Greenwald } & A 5-20 \\ \text { J. H. Jacobson } & \text { A5-20 }\end{array}$

74 Westinghouse Hanford Company

$\begin{array}{ll}\text { M. R. Adams } & H 6-01 \\ \text { W. C. Alaconis } & H 6-28 \\ \text { H. Babad } & \text { R2-78 } \\ \text { J. D. Berger } & \mathrm{L} 0-18 \\ \text { R. J. Bliss } & B 3-04 \\ \text { D. J. Brown } & B 4-63 \\ \text { J. A. Caggiano } & H 6-06 \\ \text { J. W. Cammann } & H 4-14\end{array}$

R. A. Carlson

D. L. Crockford

J. I. Dearing

H. D. Downey

K. R. Fecht

C. J. Geier

R. L. Gilchrist

V. W. Hall

W. F. Heine

F. N. Hodges

G. W. Jackson

V. G. Johnson

A. R. Johnson

K. N. Jordan

C. J. Kemp

M. K. Korenko

D. S. Landeen

M. J. Lauterbach

A. G. Law

R. E. Lerch

H. E. McGuire

R. M. Mitchell

D. R. Myers

D. J. Newl and

K. L. Petersen (15)

S. J. Phillips

R. W. Powel1

S. P. Reidel

R. C. Roos

M. R. Sackschewsky

K. R. Simpson

W. A. Skelly

J. C. Sonnichsen

L. C. Stegen

A. M. Tallman

J. A. Voogd

S. Weiss

N. R. Wing (2)

T. M. Wintczak

D. D. (Don) Wodrich

R. D. Wojtasek

D. E. Wood

J. G. Wool ard

Central Files

Environmental Data

Management Center (2)

Publications

Services (3)
H6-03

$\mathrm{H} 4-14$

H5-72

H6-27

H6-06

H6-21

L5-63

B1-59

B3-63

H6-06

H6-21

H6-06

H6-30

H6-28

H4-14

B3-08

H4-14

H6-01

H6-06

B3-63

B3-63

H6-04

H4-14

B1-58

H4-14

H4-14

H4-14

H6-06

H6-04

H4-14

H6-06

H6-03

H4-14

S4-58

H5-60

R4-03

H6-02

H4-14

H6-27

B1-59

H6-27

$\mathrm{HO}-33$

H6-05

L8-04

H6-07

L8-04 

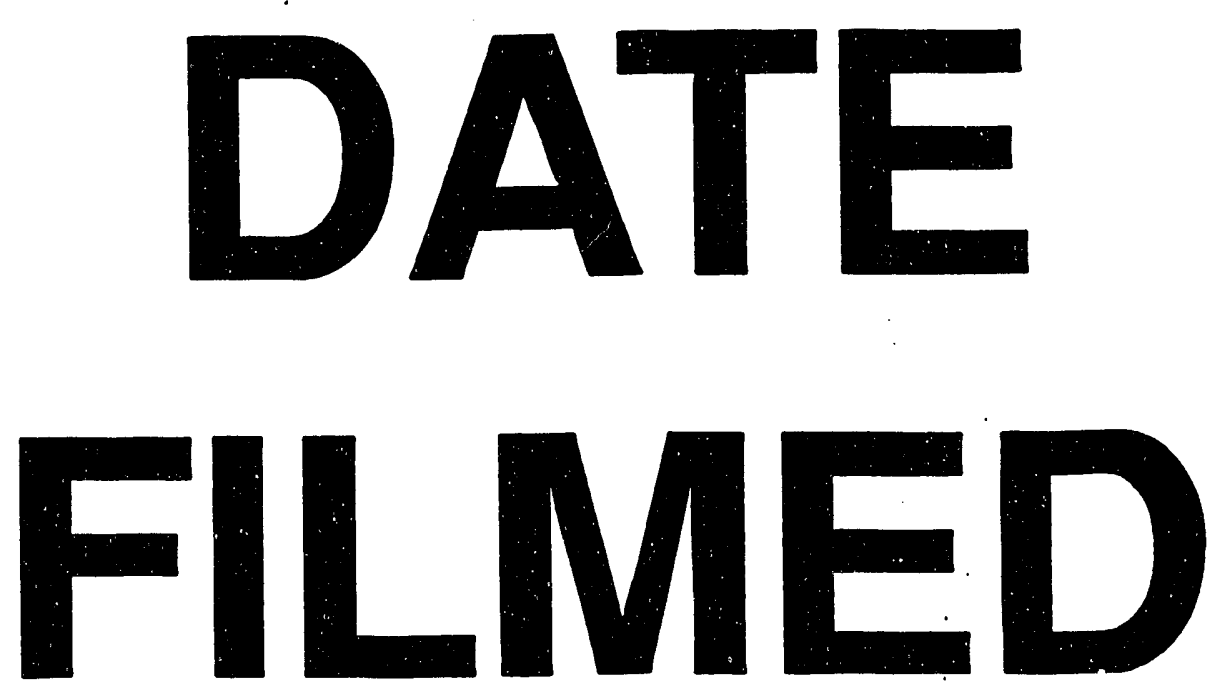

$9 / 28 / 93$
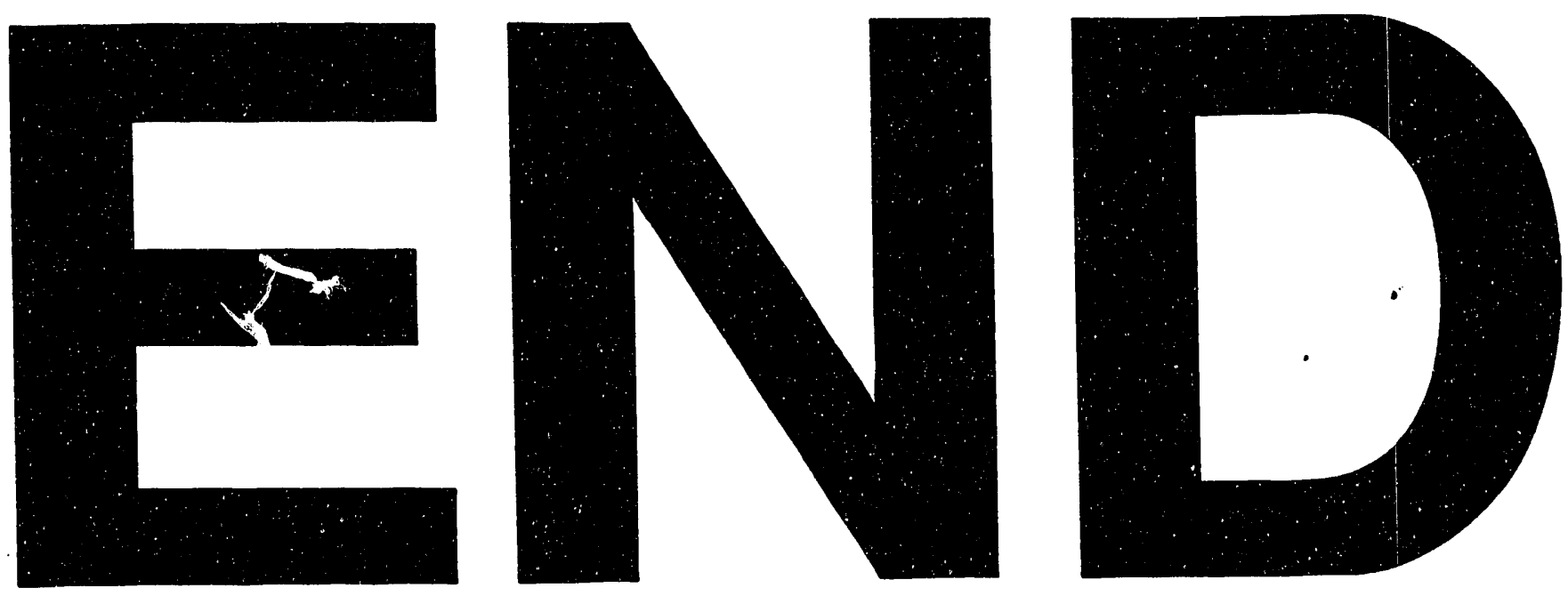
